IZA DP No. 518

The Evidence on Credit Constraints in Post-Secondary Schooling

\author{
Pedro Carneiro \\ J ames J. Heckman \\ J une 2002
}




\title{
The Evidence on Credit Constraints in Post-Secondary Schooling
}

\author{
Pedro Carneiro \\ University of Chicago
}

\author{
James J. Heckman \\ University of Chicago, American Bar Foundation and IZA Bonn
}

\author{
Discussion Paper No. 518 \\ June 2002
}

\author{
IZA \\ P.O. Box 7240 \\ D-53072 Bonn \\ Germany \\ Tel.: +49-228-3894-0 \\ Fax: +49-228-3894-210 \\ Email: iza@iza.org
}

This Discussion Paper is issued within the framework of IZA's research area The Future of Labor. Any opinions expressed here are those of the author(s) and not those of the institute. Research disseminated by IZA may include views on policy, but the institute itself takes no institutional policy positions.

The Institute for the Study of Labor (IZA) in Bonn is a local and virtual international research center and a place of communication between science, politics and business. IZA is an independent, nonprofit limited liability company (Gesellschaft mit beschränkter Haftung) supported by the Deutsche Post AG. The center is associated with the University of Bonn and offers a stimulating research environment through its research networks, research support, and visitors and doctoral programs. IZA engages in (i) original and internationally competitive research in all fields of labor economics, (ii) development of policy concepts, and (iii) dissemination of research results and concepts to the interested public. The current research program deals with (1) mobility and flexibility of labor, (2) internationalization of labor markets, (3) the welfare state and labor markets, (4) labor markets in transition countries, (5) the future of labor, (6) evaluation of labor market policies and projects and (7) general labor economics.

IZA Discussion Papers often represent preliminary work and are circulated to encourage discussion. Citation of such a paper should account for its provisional character. A revised version may be available on the IZA website (www.iza.org) or directly from the author. 
IZA Discussion Paper No. 518

June 2002

\section{ABSTRACT}

\section{The Evidence on Credit Constraints in Post-Secondary Schooling *}

This paper examines the family income-college enrollment relationship and the evidence on credit constraints in post-secondary schooling. We distinguish short-run liquidity constraints from the long-term factors that promote cognitive and noncognitive ability. Long-run factors crystallized in ability are the major determinants of the family income-schooling relationship, although there is some evidence that up to $8 \%$ of the U.S. population is credit constrained in a short-run sense. Evidence that IV estimates of the returns to schooling exceed OLS estimates is sometimes claimed to support the existence of substantial credit constraints. This argument is critically examined.

JEL Classification: $\quad$ I28, D33, H43

Keywords: $\quad$ human capital, return to education, credit constraints

James J. Heckman

University of Chicago

Dept. of Economics

1126 East 59th St.

Chicago, IL 60637

USA

Tel.: $+1(773)$ 702-0634

Fax: +1 (773) 702-8490

Email: jheckman@midway.uchicago.edu

\footnotetext{
*This research was supported by NSF-SES 0079195 and NICHD-40-4043-000-85-261 and grants from the Donner Foundation and The American Bar Foundation. Carneiro was also supported by Fundacao Ciencia e Tecnologia and Fundacao Calouste Gulbenkian. This paper was presented as the Economic Journal Lecture at the Royal Economic Society Annual Meetings, Durham, England, April 2001. We have benefitted from comments from Partha Dasgupta, Steve Levitt, Costas Meghir, Kathleen Mullen and Casey Mulligan on various versions of this paper. We have also benefited from our collaboration with Edward Vytlacil and from the research assistance by Jingjing Hsee and Dayanand Manoli.
} 


\section{Introduction}

This paper interprets the evidence on the relationship between family income and college attendance. Figure 1 displays aggregate time series college participation rates for 18-24 year-old American males classified by their parental income. Parental income is measured in the child's late adolescent years. There are substantial differences in college participation rates across family income classes in each year. This pattern is found in many other countries (see the essays in Blossfeld and Shavit, 1993). In the late 1970s or early 1980s, college participation rates start to increase in response to rising returns to schooling, but only for youth from the top income groups. This differential educational response by income class promises to perpetuate or widen income inequality across generations and among race and ethnic groups.

There are two, not necessarily mutually exclusive, interpretations of this evidence. The common interpretation of the evidence and the one that guides policy is the obvious one. Credit constraints facing families in a child's adolescent years affect the resources required to finance a college education. A second interpretation emphasizes more long-run factors associated with higher family income. It notes that family income is strongly correlated over the life cycle. Families with high income in the adolescent years are more likely to have high income throughout the child's life at home. Better family resources in a child's formative years are associated with higher quality of education and better environments that foster cognitive and noncognitive skills.

Both interpretations of the evidence are consistent with a form of credit constraint. The first, more common, interpretation is clearly consistent with this point of view. But the second interpretation is consistent with another type of credit constraint: the inability of the child to buy the parental environment and genes that form the cognitive and noncognitive abilities required for success in school. This interpretation renders a market failure as a type of credit constraint. ${ }^{1}$

This paper argues on quantitative grounds that the second interpretation of Figure 1 is by far the more

\footnotetext{
${ }^{1}$ Of course, the suggested market failure is whimsical since the preferences of the child are formed, in part, by the family into which he/she is born. Ex post, the child may not wish a different family, no matter how poor the family.
} 
important one. Controlling for ability formed by the mid teenage years, parental income plays only a minor role. The evidence from the US presented in this paper suggests that at most $8 \%$ of American youth are subject to short-term liquidity constraints that affect their post-secondary schooling. Most of the family income gap in enrollment is due to long-term factors that produce the abilities needed to benefit from participation in college.

The plan of this paper is as follows: We first state the intuitive arguments justifying each interpretation. We then consider more precise formulations starting with an influential argument advanced by Card (2001) and others. That argument claims that evidence that instrumental variables (IV) estimates of the wage returns to schooling (the Mincer coefficient) exceed least squares estimates (OLS) is consistent with shortterm credit constraints. We make the following points about this argument: (1) The instruments used in the literature are invalid. Either they are uncorrelated with schooling or they are correlated with omitted abilities. (2) Even granting the validity of the instruments, instrumental variables estimates of the return to schooling may exceed least squares estimates even if there are no short-term credit constraints. A large body of evidence on comparative advantage in the labor market is consistent with IV > OLS. (3) The OLS-IV argument neglects the choice of quality of schooling. Constrained people may choose low-quality schools and have lower estimated Mincer coefficients ("rates of return") and not higher ones. Moreover, accounting for quality, the instruments used in the literature are invalid because they are determinants of potential earnings.

We then move on to consider other arguments advanced in the literature in support of the empirical importance of short-term credit constraints: (1) Kane (1994) claims that the sensitivity of college enrollment to tuition is greater for people from poorer families. Greater tuition sensitivity of the poor, even if empirically true, does not prove that they are constrained. Kane's empirical evidence has been challenged by Cameron and Heckman $(1999,2001)$. Conditioning on ability, responses to tuition are uniform across income groups. (2) Cameron and Heckman also show that adjusting for long-term family factors (measured by ability or parental background) mostly eliminates ethnic-racial gaps in schooling. We extend their analysis to eliminate most of the family income gaps in enrollment by conditioning on long-term factors. (3) We also examine a recent qualification of the Cameron-Heckman analysis by Ellwood and Kane (2000), 
who claim to produce evidence of substantial credit constraints. We qualify their qualification. We find that at most $8 \%$ of American youth are credit constrained in the short-run sense. For many dimensions of college attendance (delay, quality of school attended and completion), adjusting for long-term factors eliminates any role for short-term credit constraints associated with family income. (4) We also scrutinize the arguments advanced in support of short-term credit constraints that (a) the rate of return to human capital is higher than that of physical capital and (b) rates of return to education are higher for individuals from low-income families. We also review some of the main findings in the empirical literature.

The evidence assembled here suggests that the first order explanation for gaps in enrollment in college by family income is long-run family factors that are crystallized in ability. Short-run income constraints play a role, albeit a quantitatively minor one. There is scope for intervention to alleviate these short-term constraints, but one should not expect to eliminate the enrollment gaps in Figure 1 by eliminating such constraints.

\section{Family Income and Enrollment in College}

This relationship between family income and the college attendance of children can be interpreted in several, not necessarily mutually exclusive, ways. The first and most popular interpretation emphasizes that credit constraints facing families in a child's adolescent years affect the resources required to finance a college education. The second interpretation emphasizes the long-run factors associated with higher family income.

The argument that short-term family credit constraints are the most plausible explanation for the relationship depicted in Figure 1 starts by noting that human capital is different from physical capital. With the abolition of slavery and indentured servitude, there is no asset market for human capital. People cannot sell rights to their future labor earnings to potential lenders in order to secure financing for their human capital investments. Even if they could, there would be substantial problems in enforcing performance of contracts on future earnings given that persons control their own labor supply and the effort and quality of their work. The lack of collateral and the inability to monitor effort are widely cited reasons for current 
large-scale government interventions to finance education.

If people had to rely on their own resources to finance all of their schooling costs, undoubtedly the level of educational attainment in society would decline. To the extent that subsidies do not cover the full costs of tuition, persons are forced to raise tuition through private loans, through work while in college or through foregone consumption. This may affect the choice of college quality, the content of the educational experience, the decision of when to enter college, the length of time it takes to complete schooling, and even graduation from college. Children from families with higher income have access to resources that children from families with lower income do not have, although children from higher-income families still depend on the good will of their parents to gain access to funds. Limited access to credit markets means that the costs of funds are higher for the children of the poor, and this limits their enrollment in college ${ }^{2}$. This story apparently explains the evidence that shows that the enrollment response to the rising educational premium that began in the late 1970s or early 1980s was concentrated in the top half of the family-income distribution. Low-income whites and minorities began to respond to the rise in the return to college education only in the 1990s. The reduction in the real incomes of families in the bottom half of the family income distribution coupled with a growth in real tuition costs apparently contributes to growing disparity between the college attendance of the children of the rich and of the poor.

An alternative interpretation of the same evidence is that long-run family and environmental factors play a decisive role in shaping the ability and expectations of children. Families with higher levels of resources produce higher-quality children who are better able to perform in school and take advantage of the new market for skills.

Children whose parents have higher income have access to better-quality primary and secondary schools. Children's tastes for education and their expectations about their life chances are shaped by those of their parents. Educated parents are better able to develop scholastic aptitude in their children by assisting and directing their studies. What is known about cognitive ability is that it is formed relatively early in life

\footnotetext{
${ }^{2}$ Evidence on educational responses to tuition subsidies is sometimes mistakenly interpreted as evidence on credit constraints. The purchase of education is governed by the same principles that govern the purchase of other goods. The lower the price, the more likely are people to buy the good. Dynarski (2000) presents recent evidence about the strength of these tuition effects that is consistent with a long line of research. In addition, there is, undoubtedly, a consumption component to education. Families with higher incomes may buy more of the good for their children and buy higher quality education as well. This will contribute to the relationship displayed in Figure 1.
} 
and becomes less malleable as children age. By age 14, intelligence as measured by IQ tests seems to be fairly well set. (See the evidence summarized in Heckman, 1995). Noncognitive skills appear to be more malleable until the late adolescent years. (See Heckman, 2000 and Carneiro, Heckman and Manoli, 2002). The influences of family factors that are present from birth through adolescence accumulate over many years to produce ability and college readiness. By the time individuals finish high school, and scholastic ability is determined, the scope of tuition policy for promoting college attendance through boosting cognitive and noncognitive skills is greatly diminished.

The interpretation that stresses the role of family and the environment does not necessarily rule out short-term borrowing constraints as a partial explanation for Figure 1. However, if the finances of poor but motivated families hinder them from providing decent elementary and secondary schooling for their children, and produce a low level of college readiness, government policy aimed at reducing the short-term borrowing constraints for the college expenses of those children during their college-going years is unlikely to be effective. Policy that improves the environments that shape ability will be a more effective avenue for increasing college enrollment in the long run. The issue can be settled empirically. Surprisingly, little data have been brought to bear on this question until recently.

In this paper, we critically examine the evidence in the literature and present new arguments and evidence of our own. There is evidence for both short-run and long-run credit constraints. Long-run family influence factors produce both cognitive and noncognitive ability which vitally affect schooling. Differences emerge early and, if anything, are strengthened in school. Conditioning on long-term factors eliminates most of the effect of family income in the adolescent years on college enrollment decisions for most people, except for a small fraction of young people. We reach similar conclusions for other dimensions of college participation - delay of entry, final graduation, length of time to complete school and college quality. For some of those dimensions, adjusting for long-run factors eliminates or even overadjusts the family income gaps. At most, $8 \%$ of American youth are constrained. Credit constraints in the late adolescent years play a role for a small group of youth who can be targeted.

In the next section, we review and criticize the argument that comparisons between IV and OLS estimates of the returns to schooling are informative about the importance of credit constraints. 


\section{OLS, IV and Evidence On Credit Constrained Schooling}

A large body of literature devoted to the estimation of "causal" effects of schooling has found that in many applications instrumental variable estimates of the return to schooling exceed OLS estimates. (See Griliches, 1977; Card, 1999, 2001.) Researchers have used compulsory schooling laws, distance to the nearest college or tuition as their instruments to estimate the return to schooling.

Since IV can be interpreted as estimating the return for those induced to change their schooling status by the selected instrument, finding higher returns for changers suggests that they are credit constrained persons who face higher marginal costs of schooling. This argument has become very popular among applied researchers. (See e.g. Kane, 2001.)

For three reasons, this evidence is not convincing on the issue of the existence of credit constraints. First, the validity of the instruments used in this literature is questionable. Second, even granting the validity of the instruments, the IV-OLS evidence is consistent with models of self-selection or comparative advantage in the labor market even in the absence of credit constraints (Carneiro, Heckman and Manoli, 2002; Heckman, 2001; Carneiro, Heckman and Vytlacil, 2001). Third, the argument ignores the quality margin. As the evidence presented in Carneiro, Heckman and Manoli (2002) shows, one manifestation of credit constraints is lower-quality schooling. Students will attend two-year schools instead of four-year schools, or will attend lower-quality schools at any level of attained years of schooling. Moreover, even if the OLS-IV comparison were convincing, the IV procedure does not identify the credit constrained people. We now elaborate on these points.

\section{Models of Heterogeneous Returns}

A major development in economics is recognition of heterogeneity in response to education and other interventions as an empirically important phenomenon (Heckman, 2001). In terms of a familiar regression model for schooling $S$, we may write wages as

$$
\ln W=\alpha+\beta S+\varepsilon
$$


where $E(\varepsilon)=0$ and $\beta$ varies among people, and both $\beta$ and $\varepsilon$ may be correlated with $S$. In that case, conventional intuitions about least square bias, ability bias and the performance of instrumental variables break down.

Another representation of (1) is in terms of potential outcomes (see Heckman and Robb, 1986). Let $\ln W_{1}$ be the wage of a person if schooled; $\ln W_{0}$ is the wage if not schooled.

$$
\begin{array}{ll}
\ln W_{1}=\mu_{1}+U_{1} & E\left(U_{1}\right)=0 \\
\ln W_{0}=\mu_{0}+U_{0} & E\left(U_{0}\right)=0
\end{array}
$$

so $\beta=\ln W_{1}-\ln W_{0}=\mu_{1}-\mu_{0}+U_{1}-U_{0}, \alpha=\mu_{0}$, and $\varepsilon=U_{0} . \quad \beta$ is the marginal return to schooling. There is a distribution of $\beta$ in the population. No single number describes "the" rate of return to education. Many different "effects" of schooling can be defined and estimated. Different estimators define different parameters. Different instruments define different parameters. None of these parameters necessarily answers policy-relevant questions (Heckman and Vytlacil, 2001; Heckman, 2001).

The Roy model of income distribution is based on a simple schooling rule:

$$
\begin{aligned}
& S=1 \text { if } W_{1}-W_{0}-C>0 \\
& S=0 \text { otherwise }
\end{aligned}
$$

where $C$ is direct cost ("tuition"). This model gives rise to comparative advantage in the labor market, which has been shown to be empirically important in Sattinger (1978, 1980), Willis and Rosen (1979), Heckman and Sedlacek (1985, 1990), Carneiro, Heckman and Vytlacil (2001) and others. Models of comparative advantage in earnings differ from conventional models of earnings by recognizing two or more potential skills for each person rather than the one skill efficiency units view of the human capital model that dominated the early discussion of ability bias (Griliches, 1977). The early discussion of ability bias implicitly assumed that $U_{1}=U_{0}$ so $\beta$ is a constant for all persons given personal characteristics $X$.

\section{Invalid Instruments}


Putting aside for the moment the issue of heterogeneity in rates of return, there is considerable doubt about the validity of the instruments used in the literature. Here we consider a common coefficient model of schooling and earnings ( $\beta$ the same for everyone conditional on characteristics $X$ ) and present conditions under which $\hat{\beta}_{I V}>\hat{\beta}_{O L S}$ if the variable we are using as an instrument is correlated with the residual of the wage equation. We show empirical evidence that is suggestive that this is an empirically important problem.

The ability bias literature considered the ability bias problem to be an omitted variables problem. In the true model,

$$
\ln W=\alpha+\beta S+\gamma A+\varepsilon
$$

where $A$ is ability and $\beta$ is the (homogeneous) common return to schooling $U_{1}=U_{0}=\varepsilon$. However, in traditional formulations $\mathrm{A}$ is an omitted variable. To focus on the central argument in this literature, suppose that $\operatorname{COV}(S, \varepsilon)=0, \operatorname{COV}(S, A)>0$ and that $\gamma>0$ (individuals of high ability take more schooling and ability has a positive effect on wages). Suppose we have a candidate instrument $Z$ with the properties that $C O V(Z, \varepsilon)=0, C O V(Z, S) \neq 0$ but $C O V(Z, A) \neq 0$, so $Z$ is an invalid instrument. Then

$$
\begin{aligned}
\operatorname{plim} \hat{\beta}_{O L S} & =\beta+\gamma \frac{\operatorname{COV}(S, A)}{V(S)} \\
\operatorname{plim} \hat{\beta}_{I V} & =\beta+\gamma \frac{\operatorname{COV}(Z, A)}{\operatorname{COV}(Z, S)}
\end{aligned}
$$

so $\operatorname{plim} \hat{\beta}_{I V}>\operatorname{plim} \hat{\beta}_{O L S}$ if

$$
\frac{\operatorname{COV}(Z, A)}{\operatorname{COV}(Z, S)}>\frac{\operatorname{COV}(S, A)}{V(S)}
$$

(since $\gamma>0$ ), where $V(S)$ is the variance of $S$. If $C O V(Z, S)>0$, this condition can be rewritten as follows:

$$
\frac{C O V(Z, A)}{[V(A) V(Z)]^{\frac{1}{2}}}>\frac{C O V(S, A) C O V(Z, S)}{V(S)[V(A) V(Z)]^{\frac{1}{2}}}
$$

or

$$
\rho_{Z A}>\rho_{S A} \rho_{S Z}
$$


where the $\rho_{X Y}$ is the correlation between $X$ and $Y$. If $C O V(Z, S)<0$, the ordering is reversed and

$$
\rho_{Z A}<\rho_{S A} \rho_{S Z}
$$

Few data sets contain measures of ability. However the NLSY data (see Bureau of Labor Statistics, 2001) contains AFQT which is a measure of ability. Using this data we can test the validity of alternative commonly used instruments by estimating the correlation between $Z$ and $A$. Table 1 presents evidence on this and the other correlations. (The sources of the data for this and other tables and figures in this paper are given in the appendix.) The final column reports whether the pattern of correlations predicted under the bad instrument hypothesis is found and is statistically significant. This table suggests that the literature is plagued by bad instrumental variables: they are either correlated with $S$ and $A$ or they are

uncorrelated with $S$. The conditions required for plim $\hat{\beta}_{I V}>\operatorname{plim} \hat{\beta}_{O L S}$ hold for most instruments which suggests that the evidence that $\hat{\beta}_{I V}>\hat{\beta}_{O L S}$ may be just a consequence of using bad instruments ${ }^{3}$, and says nothing about credit constraints.

\section{Comparative Advantage and Negative Selection Bias}

Suppose, provisionally, that the instruments are valid. We now return to a case where $\beta$ varies across people and people self-select into schooling based on $\beta$. In the simple two-skill Roy model with no direct costs $(C=0)$, it must be the case that persons with the highest returns to schooling $(\beta)$ select into schooling (choose $S=1$ ), while those with the lowest returns do not. This implies that the average return to schooling for those who go to school,

$$
E(\beta \mid S=1)=E\left(\ln W_{1}-\ln W_{0} \mid S=1\right),
$$

is higher than the return to persons just at the margin of going to school. The same analysis holds when $C$ is introduced, provided that it is not too strongly positively correlated with $W_{1}-W_{0}{ }^{4}$. In this case,

\footnotetext{
${ }^{3}$ We perform this test using the original AFQT tests and the test corrected for the endogeneity of schooling on test scores using the methods developed and applied in Hansen, Heckman and Mullen (2002). We get the same results whether or not we adjust the test score for the effect of schooling on AFQT. Results are available from the authors on request.

${ }^{4}$ Precise conditions are given in Carneiro, Heckman and Vytlacil (2001).
} 
which is illustrated in Figure 2, the marginal entrant into schooling has a lower return than the average person attending school. Figure 2 plots the average returns to people with different characteristics as a function of how those characteristics affect the probability of going to college. In this figure people with characteristics that make them more likely to go to school have higher returns on average than those with characteristics that make them less likely to go to school.

If the costs of attending school are sufficiently positively correlated with returns, the shape of Figure 2 does not necessarily arise. If persons with high returns $(\beta)$ also face high costs, then marginal entrants may have a higher return than the average return of persons who go to school $(E(\beta \mid S=1))$. This could arise if people face credit constraints, e.g., dumb kids have rich parents and bright kids have poor parents. This case is illustrated in Figure 3.

Comparing the returns of people who attend school $(E(\beta \mid S=1))$ with the returns of people at the margin of attending school would be one way to test the existence of credit constraints. Under standard assumptions used in discrete choice and sample selection models (see Vytlacil, 2002, for a statement of these conditions), valid instrumental variable estimators identify the persons who change schooling status in response to the intervention, and are at (or near) the margin defined by the instrument (Imbens and Angrist, 1994; Card, 2001).

If IV estimators of the return to schooling are above $E(\beta \mid S=1)$, then it is plausible that credit constraints are operative - persons attracted to school by a change in a policy (or an instrument) earn more than the average person who attends school (see Figure 2). This idea is empirically operationalized in the literature by comparing OLS estimators of the coefficient on $S$ to the IV estimator. Griliches (1977) first noted that IV estimates of the return to schooling often exceed OLS estimates. Card (1999, 2001) reports a systematic body of evidence consistent with Griliches' finding and interprets this as evidence of important credit constraints in the financing of schooling.

However even if the instruments are valid the test is not informative because the least squares estimator does not identify

$$
E(\beta \mid S=1)=E\left(\ln W_{1}-\ln W_{0} \mid S=1\right) .
$$


Rather it identifies

$$
E(\ln W \mid S=1)-E(\ln W \mid S=0)=E(\beta \mid S=1)+\left\{E\left(U_{0} \mid S=1\right)-E\left(U_{0} \mid S=0\right)\right\} .
$$

In a model without variability in the returns to schooling, $E(\beta \mid S=1)=E(\beta)=\bar{\beta}$ is the same constant for everyone, so it is plausible that if $U_{0}$ is ability, the second term in parentheses will be positive (more able people attend school). This is the model of ability bias that motivated Griliches (1977). As noted by Willis and Rosen (1979), and confirmed in a nonparametric setting by Carneiro, Heckman and Vytlacil (2001), if there is comparative advantage, the term in brackets may be negative. People who go to school may be the worst persons in the $W_{0}$ distribution, i.e. $E\left(U_{0} \mid S=1\right)-E\left(U_{0} \mid S=0\right)<0$ (even though they could be the best persons in the $W_{1}$ distribution). This could offset the positive $E\left(U_{1}-U_{0} \mid S=1\right)$ and make the OLS estimate below that of the IV estimate. Only if the sorting on skills is sufficiently weakly negative (or positive) will the Card test be informative on the question of credit rationing.

Symmetrically, if there is credit rationing (the marginal entrant induced into schooling faces a higher return than is experienced by the average person who attends school), OLS estimates of the return to schooling might exceed IV estimates if sorting is sufficiently strongly positive $\left(E\left(U_{0} \mid S=1\right)-E\left(U_{0} \mid S=\right.\right.$ $0)>0$ ). Thus the proposed test for credit constraints has no power under either null hypothesis: binding credit constraints or no credit constraints ${ }^{5}$.

The fallacy in the test is to assume that the OLS estimate is at least as large as the average return to people who take schooling. In a model of comparative advantage of the sort confirmed in a series of empirical studies of labor markets, nothing guarantees this condition. Carneiro, Heckman and Vytlacil (2001) present evidence from several data sets that the condition is in fact violated and $E\left(U_{0} \mid S=1\right)-$ $E\left(U_{0} \mid S=0\right)<0$.

We estimate the returns to college using IV and OLS in several data sets and using different instruments and we find that $\beta_{I V}>\beta_{O L S}$ is a robust empirical result. However when we estimate the marginal return for people with different characteristics, i.e. the effect of treatment for people at different margins

\footnotetext{
${ }^{5}$ This reasoning extends easily to a model with multiple levels of schooling.
} 
of indifference between going to college and not going (see Heckman and Vytlacil, 2000; and Carneiro, Heckman and Vytlacil, 2001), we find a general declining pattern in all these data sets which indicates that the returns for the average person are higher than the returns for the marginal person. A declining marginal treatment effect means that returns are higher for individuals who go to college. We estimate that $E(\beta \mid S=1)>\beta_{I V}>\beta_{O L S}$. This declining pattern for the marginal treatment effects holds generally even when we estimate it separately for different income groups and different ability groups. See Carneiro, Heckman and Vytlacil (2001) and Carneiro, Heckman and Manoli (2002).

\section{College Quality}

The literature also neglects choice at the quality margin. Accounting for choice of quality provides yet another interpretation of the OLS-IV evidence and casts further doubt on the validity of the instruments used in this literature. We develop a two-period model of credit-constrained schooling where agents can lend but cannot borrow. We demonstrate that when agents adjust on the quality margin as well as the quantity margin, instrumental variables (e.g. policy changes) that induce constrained students to attend lower quality schools can lower the estimated Mincer return to schooling. The evidence that $\beta_{I V}>\beta_{O L S}$ can just as well be interpreted as suggesting the absence of credit constraints. This analysis also shows that Mincer returns can be very misleading guides to the true rate of return.

Consider an additively separable two-period utility function with discount rate $\rho$ :

$$
U\left(C_{0}\right)+\frac{1}{1+\rho} U\left(C_{1}\right)
$$

where $C_{0}$ and $C_{1}$ denote consumption in the first and second periods respectively. The agent possesses exogenous income flows in each period, $Y_{0}$ and $Y_{1}$. One can think of $Y_{0}$ as parental income. Individuals are constrained in their schooling choices only if they seek to borrow against future income (i.e., if saving is non-positive).

We consider three choices for schooling: not attending school, attending a low quality school and attending a high quality school. Think of $S=1$ as denoting college attendance. $S=0$ is high school attendance. $D_{i}$ is an indicator equal to one if the agent chooses quality of schooling $q_{i}, i=1,2 . q_{i}$ denotes 
the costs of schooling associated with each schooling level if the agent attends school. Finally, the wage associated with each schooling level is

$$
W(S, q)=W_{0} \prod_{i=1}^{2}\left[\phi(q)^{\left.D_{i}\right]}\right]^{S}
$$

so

$$
\ln W=\ln W_{0}+S\left[\sum_{i=1}^{2} D_{i} \ln \phi\left(q_{i}\right)\right]
$$

where $\phi\left(q_{i}\right)$ is the production function or wage output associated with the quality of level $q_{i}$. Evidence presented by Black and Smith (2002) and others suggests that high quality schooling (in college) has a substantial effect on lifetime earnings. To fix ideas, specify

$$
\phi(q)=A q^{\gamma}, A>0,0<\gamma<1
$$

so we reach a familiar Mincer-like wage equation:

$$
\ln W=\ln W_{0}+S\left[\ln A+\sum_{i=1}^{2} D_{i} \gamma \ln (q)\right]
$$

When choosing not to attend college $(S=0)$, an agent works in both the first and second periods and makes $W_{0}$ per period. In choosing to attend schooling the agent does not earn the initial wage in the first period and also pays the costs of attending school $q$; in the second period, the agent makes $W_{0} \phi(q)$. We assume $q_{2}>q_{1}>1$ and hence $\phi\left(q_{2}\right)>\phi\left(q_{1}\right)>1$. Notice that persons who attend college at a lower quality school earn a lower Mincer return but have a rate of return higher than the market interest rate.

For agents who are net savers and are not credit constrained, only ability matters, so agents with high ability attend high quality schools, agents of moderate ability attend medium quality schools, and agents of low ability do not attend school. For persons who are constrained, consumption in each period is equal to their exogenous income flow plus or minus the costs or earnings from the schooling decision. This model generalizes Becker (1975) and Card (1995) by explicitly accounting for preferences, including time 
preference. In the credit constrained economy, the three choices and their associated utilities are as follows:

a. No School: $S=0, q=0$

$$
U_{0} \equiv U\left(Y_{0}+W_{0}\right)+\frac{1}{1+\rho} U\left(Y_{1}+W_{0}\right)
$$

b. Low Quality Schooling: $S=1, q=q_{1}$

$$
U_{1} \equiv U\left(Y_{0}-q_{1}\right)+\frac{1}{1+\rho} U\left(Y_{1}+W_{0} \phi\left(q_{1}\right)\right)
$$

c. High Quality Schooling: $S=1, q=q_{2}$

$$
U_{2} \equiv U\left(Y_{0}-q_{2}\right)+\frac{1}{1+\rho} U\left(Y_{1}+W_{0} \phi\left(q_{2}\right)\right)
$$

The agent maximizes utility and chooses the schooling that yields the highest utility: take No School if $U_{0}>U_{1}, U_{2}$; take Low Quality Schooling if $U_{1}>U_{0}, U_{2}$; or take High Quality Schooling if $U_{2}>U_{1}, U_{0}$

Suppose that $A$ varies in the population and is unobserved. $\gamma, \rho$ and $\alpha$ are common parameters. $W_{0}, Y_{0}$ and $Y_{1}$ are observed. Let $X=\left(W_{0}, Y_{0}, Y_{1}\right)$ and assume $E(\ln A \mid X)=0$ and assume that selection into schooling status depends on these parameters. The higher $A$, the lower $\rho$, the higher $Y_{0}$ and the lower the cost of quality the more likely will $S=1$. These forces also work toward making people select higher quality schooling. Any estimated return to schooling depends on the quality of schooling selected.

Suppose there is a valid instrument, say a policy targeted toward low $Y_{0}$ persons, that shifts people from $S=0$ to $\left(S=1, D_{1}=1\right)$ status. It leads poor people to attend low quality schools. The Mincer return to schooling for these people is

$$
\gamma \ln q_{1} .
$$


This is smaller in general than the least squares estimator

$$
\gamma\left[\left(\ln q_{1}\right) P_{1}+\left(\ln q_{2}\right) P_{2}\right]+\{E(\ln A \mid S=1, X)-E(\ln A \mid S=0, X)\}
$$

where

$$
P_{1}=\operatorname{Pr}\left(D_{1}=1 \mid S=1, X\right)
$$

and

$$
P_{2}=\operatorname{Pr}\left(D_{2}=1 \mid S=1, X\right)
$$

and selection implies that the term in braces is positive (more able people are more likely to attend school).

The agents are credit constrained, but pick low quality schooling when they attend college. This analysis shows that when quality is added to the Becker-Card model, and it is not accounted for in the estimation, credit-constrained persons induced to attend college by a policy or an instrument directed toward low-income persons may have lower estimated returns than the average person. The estimated Mincer return is not, of course, the true rate of return.

Note further that tuition $(q)$ is not a valid instrument because it affects potential outcomes (through $\varphi(q))$. Distance is like tuition in many respects and is also unlikely to be a valid instrument. Nearby schools are generally of lower quality. This is another argument against the validity of several of the instruments commonly used in the literature.

\section{Inaccurate Targeting of Credit Constrained People}

An additional point is that in general IV does not identify the credit constrained people. IV methods do not allow us to identify the group of people for whom it would be useful to target an intervention. Using a direct method like the one described next we can identify a group of high-ability people who are not going to college and we can target policy interventions towards them. 


\section{Adjusting Family Income Gaps by Ability or Other Long-Term Fam-}

\section{ily Factors}

A more direct approach to testing the relative importance of long-run factors vs. short-run credit constraints in accounting for the evidence in Figure 1 is to condition on long-run factors and examine if there is any additional role for short-run credit constraints. Conditioning on observables also offers the promise of identifying specific subgroups of persons who might be constrained and who might be targeted by policies.

Cameron and Heckman $(1998,1999,2001)$ compare the estimated effects of family background and family income on college attendance with, and without, controlling for scholastic ability (AFQT). Measured scholastic ability is influenced by long-term family and environmental factors, which are in turn produced by the long-term permanent income of families. To the extent that the influence of family income on college attendance is diminished by the inclusion of scholastic ability in an analysis of college attendance, one would conclude that long-run family factors crystallized in AFQT scores are the driving force behind schooling attainment, and not short-term credit constraints. Fitting a lifecycle model of schooling to a subsample of the NLSY data on youth with AFQT measured before high school graduation, Cameron and Heckman examine what portion of the gap in school attendance at various levels between minority youth and whites is due to family income, to tuition costs, and to family background (see BLS, 2001, for a description of the NLSY data). They find that when they do not control for ability measured at an early age, about half ( 5 points) of the 11 point gap between black and white college attendance rates is due to family income; more than half (4 points) of the 7 point difference between Hispanics and whites is due to family income. When scholastic ability is accounted for, only one half of one point of the 11 point black-white gap is explained for family income. For Hispanics, the gap actually widens when family income is included. Equalizing ability more than accounts for minority-majority college attendance gaps. Comparable results are obtained when they adjust for parental education and family structure ${ }^{6}$. The effects of tuition on college entry are also greatly weakened when measures of ability are included. Ability, and not financial resources, in the teenage years accounts for pronounced minority-majority differences

\footnotetext{
${ }^{6}$ The authors condition on an early measure of ability not contaminated by feedback from schooling to test scores that is documented in Hansen, Heckman and Mullen (2002).
} 
in schooling attainment. The disincentive effects of college tuition on college attendance are dramatically

weakened when ability is included in the analysis of college attendance. This analysis suggests that it is long-run factors that determine college attendance, not short-term borrowing constraints, that explain the evidence in Figure 1.

It is sometimes claimed that the enrollment responses to tuition should be larger for constrained (lowincome) persons. (See Kane, 1994, and the survey in Ellwood and Kane, 2000.) This does not follow from any rigorous argument ${ }^{7}$. Table 2 taken from Cameron and Heckman (1999) explicitly addresses this issue empirically. (See in particular panels B and C. ${ }^{8}$ ). Even without adjusting for AFQT, there is no pattern in the estimated tuition effects by family income level. When they condition on ability, tuition effects become smaller (in absolute value) and no pattern by family income is apparent. Even if the argument had theoretical validity, there is no empirical support for it.

Ellwood and Kane (2000) accept the main point of Cameron and Heckman that academic ability is a major determinant of college entry. At the same time, they argue that family income operates as an additional constraint, not as powerful as academic ability, but more easily addressed by policy than ability. Figure 4 presents our version of their case using the NLSY79 (see the appendix for a brief discussion of these data). Classifying people by test score terciles, we display college enrollment rates by family income. There is a clear ordering in the high-ability group and in other ability groups as well. Persons from families with higher income are more likely to enroll in college. This ordering occurs in other data sets, even for low-ability groups. (See Carneiro, Heckman and Manoli, 2002.)

\footnotetext{
${ }^{7}$ Mulligan (1997) shows that in the context of a Becker-Tomes model that tuition elasticities for human capital accumulation are greater (in absolute value) for unconstrained people. His proof easily generalizes to more general preferences (results are available on request from the authors). By a standard argument in discrete choice Kane's claim cannot be rigorously established. Let $S=1$ if $I(t, X) \geq \varepsilon$ where $I$ is an index of net benefit from college, $t$ is tuition, $\frac{\partial I}{\partial t}<0$ and $X$ are other variables, including income. $\varepsilon$ is an unobservable psychic cost component. Then assuming that $\varepsilon$ is independent of $t, X$,

$$
\operatorname{Pr}(S=1 \mid t, X)=\int_{-\infty}^{I(t, X)} f(\varepsilon) d \varepsilon
$$

where $f(\varepsilon)$ is the density of psychic costs. Then

$$
\frac{\partial \operatorname{Pr}(S=1 \mid t, X)}{\partial t}=\left[\frac{\partial I(t, X)}{\partial t}\right] f(I(t, X)) .
$$

For constrained persons with very low income, $I(t, X)$ is small. Depending on the density of $\varepsilon$, the location of $I(t, X)$ in the support of the density, and the value of $\frac{\partial I(t, X)}{\partial t}$, constrained persons may have larger or smaller tuition responses than unconstrained persons. Thus if $\varepsilon$ is normal, and $I(t, X) \longrightarrow-\infty$ for constrained people, if the derivative is bounded, the tuition response is zero for constrained people.

${ }^{8}$ Standard errors are not presented in their paper but test statistics for hypothesis of equality are presented.
} 
These plots indicate a subsidiary, but still quantitatively important role for family income in accounting for schooling enrollment. Does this mean that short-run credit constraints are operative in the collegegoing years? Not necessarily. Family income in the adolescent years is strongly correlated with family income throughout the life cycle. In addition, long-run family resources likely produce many skills that are not fully captured by a single test score.

When we control for early family background factors (parental education, family structure and place of residence) we greatly weaken this relationship. Table 3 reports estimated gaps by income quartile relative to the top income quartile after adjustment for the covariates listed at the top of the table. These gaps are denoted "Beta" and are presented for different AFQT groups and overall for the six dimensions of college participation listed in the heading of each panel. Standard errors and $t$ statistics are presented for each estimated adjusted gap. Focusing on enrollment (Panel A), we cannot reject the hypothesis that in the high-ability group all gaps are zero (see test statistic for "All Gaps $=0$ " at the base of the panel). If we do not condition on AFQT we reject the hypothesis (see the estimates under "Total"), and find strong family income effects. Figure 5 plots the adjusted family income gaps.

Table 4 presents estimates of the percentage of the population that is credit constrained overall (figure in box) and broken down into ability - income components (rest of the table) for each of the dimensions listed in the panel headings of the table ${ }^{9}$. Thus Panel A of Table 4 presents estimates of the credit constrained (as a fraction of the entire population) by different AFQT groups. The percent credit constrained is defined as the gap between the percentage enrollment in the highest income quartile for each ability tercile and the percentage in the other income quartiles. The constrained "bright but poor" comprise $0.4 \%$ of the entire population and have an enrollment gap relative to the top income group of their top AFQT tercile of $5.73 \%$ (the latter figure is from Table 3). The strongest evidence for a constraint is in the lowest ability tercile. "Dumb rich kids" are more likely to enroll in college than are "dumb poor kids." Cumulating over all AFQT terciles, we estimate a total of $6.4 \%$ of all persons to be constrained in college enrollment.

Most of the analysis in the literature focuses on college enrollment and much less on other dimensions

\footnotetext{
${ }^{9}$ We delete an entry for years of delay because the gaps are not expressed in percentages and there is no natural way to estimate the percent constrained.
} 
of college attendance such as completion, quality of school and delay of entry into college ${ }^{10}$. In part, this emphasis is due to reliance on CPS data which is much more reliable for studying enrollment-family income relationships than completion-family income relationships.

Using the NLSY 79 data we look at other dimensions of college participation. The remaining panels of Tables 3 and 4 test for disparity and report estimates of the credit constrained for these other dimensions. When we perform a parallel analysis for college completion of four-year college (Panel B), we find no evidence of constraints and in fact overadjust college enrollment for the poor within each ability tercile. Figures 6 and 7 present the raw and adjusted gaps for completion of four-year college. There is no evidence of short-run credit constraints (see Panel B). There is evidence of short-run credit constraints for the "dumb poor" in completing two years of college, but not for the "bright poor" (see Panel C). There is weak evidence in certain cells for short-term credit constraints in years of delay of entry (panel E) but not for choice of two-year vs. four-year colleges, which is a measure of quality. Depending on the measure of college participation selected, the estimated percent constrained ranges from 0 to $8 \%$. Setting statistically insignificant gaps to zero we obtain a much smaller range of values (0-3\%). We obtain comparable results for other data sets (see Carneiro, Heckman and Manoli, 2002).

Policies that improve financing of the education of these identified subgroups will increase their human capital and may well be justified on objective cost-benefit criteria ${ }^{11}$. For these groups, the benefits to reducing delay, and promoting earlier college completion, higher college quality and graduation, are likely to be substantial. But in designing policies to harvest this benefit, it is important to target the interventions toward the constrained. Broad-based policies generate dead weight. For example, Dynarski (2001) and Cameron and Heckman (1999) estimate that 93\% of President Clinton's Hope scholarship funds, which were directed towards middle-class families, were given to children who would attend school even without the program.

While targeting the identified constrained may be good policy, it is important not to lose sight of the

\footnotetext{
${ }^{10}$ Work in school is studied in Keane and Wolpin (2001). Delay in entry is studied in Kane (1996).

${ }^{11}$ The potential economic loss from delay can be substantial. If $V$ is the economic value of attending school, and schooling is delayed one year, then the costs of delay of schooling by one year are $\frac{r}{1+r} V$ where $r$ is the rate of return. For $r=.10$, which is not out of line with estimates in the literature, this delay is $9 \%$ of the value of lifetime schooling (roughly $\$ 20,000$ ).
} 
main factors accounting for the gaps in Figure 1. Family background factors as crystallized in ability are the first order factor explaining college attendance and completion gaps.

These differences in average ability appear at early ages and persist. Figure 8 plots average PIAT-Math test scores by family income quartiles at different ages from a longitudinal study of young children (Children of NLSY79; see BLS, 2001). These differences in average test scores by income quartile are amplified by schooling, and this difference is more pronounced between different racial groups than between different income groups. (See Carneiro, Heckman and Manoli, 2002.) Even conditioning on a comprehensive set of variables, including parental education, early family income and mother's ability does not eliminate this gap for the math test score we present here. ${ }^{12}$ Gaps between scores of different racial and income groups on memory tests appear as early as age one. A major conclusion of the literature is that the ability that is decisive in producing schooling differentials is shaped early in life. If we are to substantially eliminate ethnic and income differentials in schooling, we must start early, and we cannot rely on tuition policy.

At the same time, it must be acknowledged that policies to foster ability are costly (see Heckman, 2000, and Carneiro, Heckman and Manoli, 2002). The mechanisms generating ability remain to be fully explored. Policies that efficiently target the constrained are likely to pass a rigorous cost benefit test.

\section{High Rate of Return to Schooling Compared to the Return on Phys- ical Capital}

Estimates of the rate of return to schooling, based on the Mincer earnings function, are often above $10 \%$ and sometimes as high as $15 \%$. Estimates based on instrumental variables are especially high. See, for example, the evidence surveyed by Card $(1999,2001)$. It is sometimes claimed that these returns are very high and therefore people are credit constrained or some other market failure is present (see Krueger, 2002).

However, the cross-section Mincerian rate of return to schooling does not, in general, estimate the internal rate of return to schooling. See Heckman, Lochner and Taber (1998) for an example where cross-

\footnotetext{
${ }^{12}$ For other test scores analyzed in Carneiro, Heckman and Manoli, (2002), it is possible to eliminate racial gaps at early ages.
} 
section rates of return are uninformative about the return to schooling that any person faces. Heckman, Lochner and Todd (2001) state the conditions under which the Mincerian rate of return will be equal to the internal rate of return to schooling. Even if these conditions are satisfied, implicit comparisons are usually made against the risk-free interest rate. However this is not the relevant comparison. Carneiro, Hansen and Heckman (2001a,b) estimate considerable uncertainty in the returns to school. Furthermore, issues of illiquidity and irreversibility of the investment may also drive the premium on human capital far above the safe interest rate (see Judd, 2000). Comparisons of Mincer returns and returns to capital are intrinsically uninformative about the existence of credit constraints or the need for intervention in human capital markets.

\section{Are Rates of Return to Schooling Higher for Persons from Low-}

\section{Income Families?}

If low-income families are credit constrained, then at the margin the returns to schooling for their children should be higher since they are investing less than the efficient amount (assuming equal technology across families). We have already established that if choices made at the quality margin, the estimated Mincer return may be lower for constrained persons, unless adjustments for quality are made. The empirical literature, which does not adjust for quality, finds that returns to school are higher for high-ability people than for low-ability people. See for example Meghir and Palme (1999), Cawley, Heckman and Vytlacil (2000), Taber (2001) or the evidence in Carneiro, Heckman and Manoli (2002). Family income and child ability are positively correlated so one would expect higher returns to schooling for children of high-income families just for this reason. Altonji and Dunn (1996) find in their preferred empirical specification that the returns to schooling are higher for children of more educated families than for children of less educated families. There is no evidence that rates of return to schooling are higher for children from low-income families than for children from high-income families ${ }^{13}$.

\footnotetext{
${ }^{13}$ The take-up rate on Pell Grants and Perkins Loans targeted towards students from low income families is low (See Orfield, 1992). Many more people are eligible for support than those who claim it. Binding borrowing constraints are not a plausible explanation for the lack of utilization of these potential resources. Kane (1999) suggests that nonmonetary costs of applying for financial aid may be high especially for low income people because the application process is complex. He argues that
} 


\section{Additional Evidence from the Literature}

Cameron and Heckman (1998) analyze the determinants of grade by grade schooling attainment for cohorts of American males born between 1908 and 1964. Consistent with the notion that family income and family background factors reflect long-run and not short-term influences on schooling attainment, they find income and family background factors are powerful determinants of schooling completion from elementary school through graduate school. An appeal to borrowing constraints operating in the college years is not required to explain the relationship between family income and college attendance decisions and the stability of the relationship over long periods of time.

Cameron and Taber (2001) examine the importance of borrowing constraints in a model that incorporates the insight that both schooling choices and returns to schooling will be influenced by borrowing constraints. Using a variety of methods, they find no evidence that borrowing constraints play a role in explaining the years of schooling attained of recent cohorts of American youth. Keane and Wolpin (2001) estimate a more explicit sequential dynamic model and reach the same conclusion. Students are estimated to be short-run constrained but alleviate the constraints through working. Relaxing the budget constraint barely budges schooling decisions but affects work while in school. Neither study looks at delay or quality effects which we have found to be quantitatively important (Carneiro, Heckman and Manoli, 2002; Kane, 1996). Stanley (1999) studies the impact of the G.I. Bill on college-going decisions of Korean War Veterans. Consistent with our story, he finds that most college subsidies were used by veterans from families in the top half of the socioeconomic distribution. When she studies the effects of the HOPE program in Georgia, Dynarski (2000) finds that it benefits mostly middle and higher-income students. However the elasticity of enrollment to tuition subsidies in this sample is as high as anywhere else in the literature: middle and higher-income people do not seem to respond more elastically to education subsidies than lower-income people. This is consistent with the evidence from Cameron and Heckman presented in Section 4. Shea (2000) estimates the effect of a measure of parental income on schooling using the Panel Survey of Income

decreasing these costs may be a more promising avenue for relaxing financing constraints for low income people than expanding existing programs. He provides no evidence for this conjecture. An alternative explanation consistent with our evidence and that is reported in Carneiro, Heckman and Manoli (2002) is that many eligible persons perceive that even with a substantial tuition subsidy, the returns to college education for them are too low to pay for the foregone earnings required to attend school. Risk aversion due to the uncertainty of income flows may also reduce the returns relative to the benefits. 
Dynamics (see Hill, 1992, for a description of this dataset). Controlling for parental background variables, he finds an effect of his measure of family income on schooling, controlling for ability. However, using instrumental variables he estimates no effect of his measure of family income on schooling attainment and he interprets this result as evidence of no credit constraints ${ }^{14}$.

\section{Conclusion}

In this paper we examine arguments about the strength of credit constraints in schooling that are made in the literature. We evaluate the available evidence and present new evidence using American data.

Some of the evidence in the literature is uninformative on this question. The leading example is the IVOLS evidence discussed in Section 3. The literature on price effects and tuition subsidies in general is also not very informative on this question since it does not separate price effects from borrowing constraints.

The observed correlation between family income and college attendance can be interpreted as arising in two different ways: from short-run credit constraints or from long-run family effects. The latter are quantitatively more important, even though we identify a group of people (at most $8 \%$ of the population) who seem to be facing short-run credit constraints. The first order factors accounting for the gaps in Figure 1 are long-term factors that cannot easily be offset by tuition policy or supplements to family income in the adolescent years of prospective students.

All of our empirical analysis is for contemporary American society where a substantial edifice of financial aid to support post-secondary education is in place. Our assessment of the limited role of short-run credit constraints in explaining contemporary American educational gaps is, no doubt, in part due to the successful operation of these policies which were designed to eliminate such constraints. Substantial reductions in the generosity of educational benefits would undoubtedly affect participation in college although they would operate primarily through price effects. However, the evidence in Blossfeld and Shavit (1993), Cameron

\footnotetext{
${ }^{14}$ Shea splits his sample into children of educated and uneducated parents. He finds an effect of his measure of income on the schooling attainment of the children of the latter. Krueger (2002) interprets this as evidence for credit constraints. However Shea's measure of income is an average income over every year the family is sampled irrespective of the age of the child. It is a long run measure of permanent income for some families for which data are available over the life cycle of the family and the child and a short run measure when the sampling process starts in the child's adolescent years. Thus Shea's estimated income effect combines short run and long run effects in an uninterpretable fashion and is thus uninformative on the issue of the empirical importance of short run credit constraints.
} 
and Heckman (1998) and Cossa (2000) suggests the universal first order importance of long-term family influences on educational attainment. Gaps in educational attainment related to family background arise in many different environments including those with free tuition and no restrictions on college entry. This evidence points to the powerful role of the long-term factors that we have emphasized in this paper.

\section{$9 \quad$ References}

Altonji, J. and T. Dunn (1996). "The Effects of Family Characteristics on the Return to Education," Review of Economics and Statistics 78 (4): 692-704.

Becker, G. (1975), "Human Capital and The Personal Distribution of Income: An Analytic Approach"

(W. S. Woytinski Lecture), In Human Capital, second edition, New York: Columbia University Press.

Black D. and J. Smith (2002). "How Robust is the Evidence on the Effects of College Quality" Evidence From Matching," Working paper, University of Western Ontario.

Blossfeld, H. and Y. Shavit (1993). Persistent Inequality: Changing Educational Attainment in Thirteen Countries, Boulder, Co: Westview Press.

Bureau of Labor Statistics (2001). NLS Handbook 2001. Washington, D.C.: U.S. Department of Labor.

Cameron, S. and Heckman, J. (1998). "Life Cycle Schooling and Dynamic Selection Bias: Models and Evidence for Five Cohorts of American Males," Journal of Political Economy, 106(2): 262-333.

(1999). “Can Tuition Policy Combat Rising Wage Inequality?" In M. Kosters, ed., Financing

College Tuition: Government Policies and Educational Priorities. Washington: American Enterprise Institute Press.

(2001). "The Dynamics of Educational Attainment for Black, Hispanic, and White Males."

Journal of Political Economy, 109: 455-99.

Cameron, S. and Taber, C. (2001). "Borrowing Constraints and the Returns to Schooling," NBER, Working Paper No. w7761.

Card, D. (1995). "Earnings, Schooling, and Ability Revisited," Research in Labor Economics, 14: 
(1999). "The Causal Effect of Education on Earnings" in Ashenfelter, O. and Card, D. eds., Handbook of Labor Economics, Vol 3A. Amsterdam: Elsevier Science, North-Holland, pp.1801-63.

_-_- (2001). "Estimating the Return to Schooling: Progress on Some Persistent Econometric Problems." Econometrica, 69(5): 1127-60.

Carneiro, P., K. Hansen and J. Heckman (2001a). "Educational Attainment and Labor Market Outcomes: Estimating Distributions of the Returns to Educational Interventions," unpublished paper presented as Klein Lecture, University of Pennsylvania, September 2001; First Draft presented at Midwest Econometrics Group (MEG), October, 2000, forthcoming, International Economic Review, 2002.

Carneiro, P. K. Hansen and J. Heckman. (2001b). "Removing the Veil of Ignorance Assessing The Distributional Impacts of Social Policies", NBER Working Paper No. 8840, and forthcoming, Swedish Economic Policy Review.

Carneiro, P., J. Heckman and D. Manoli (2002), "Human Capital Policy", In J. Heckman and A. Krueger, Inequality in America: What Role for Human Capital Policies. Cambridge: MIT Press, forthcoming 2003.

Carneiro, P., J. Heckman and E. Vytlacil (2001). "Estimating the Rate of Return to Education When It Varies Among Individuals." Paper presented as the Economic Journal Lecture at the Royal Economic Society meeting, Durham, England, April 2001. Also presented as the Review of Economics and Statistics Lecture, Harvard Univ., April 2001.

Cawley, J., J. Heckman and E. Vytlacil (2000). "Understanding the Role of Cognitive Ability in Accounting for the Recent Rise in the Return to Education" In K. Arrow, S. Bowles, S. Durlauf, eds., Meritocracy and Economic Inequality. Princeton: Princeton University Press.

Cossa, R. (2000), "Determinants of school attainment in Argentina: An empirical analysis with extensions to policy evaluation", unpublished Ph.D. Dissertation, The University of Chicago.

Dynarski, S. (2000). "Hope for Whom? Financial Aid for the Middle Class and Its Impact on College Attendance," National Tax Journal, 53: 629-62.

(2001). "Does Aid Matter? Measuring the Effects of Student Aid on College Attendance and 
Completion," Working paper, Harvard University.

Ellwood, D. and T. Kane. (2000). "Who is Getting a College Education?: Family Background and the Growing Gaps in Enrollment" in S. Danziger and J. Waldfogel, eds., Securing the Future. New York: Russell Sage.

Griliches, Z. (1977). "Estimating the Returns to Schooling: Some Econometric Problems," Econometrica, 45(1): 1-22.

Hansen, K., J. Heckman and K. Mullen (2002). "The Effect of Schooling and Ability on Achievement Test Scores," forthcoming, Journal of Econometrics.

Heckman, J. (1995), "Lessons from the Bell Curve", Journal of Political Economy, 103(5): 1091-1120.

Heckman, J. (2000). "Policies to Foster Human Capital." Research in Economics, 54(1): 3-56.

_-__- (2001). "Micro Data, Heterogeneity, and the Evaluation of Public Policy: Nobel Lecture," Journal of Political Economy, 109(4): 673-748.

Heckman, J., L. Lochner and C. Taber. (1998) "Explaining Rising Wage Inequality: Explorations with a Dynamic General Equilibrium Model." Review of Economic Dynamics,1: 1-58.

Heckman, J., L. Lochner, and P. Todd. (2001). "Fifty Years of Mincer Regressions." Unpublished manuscript. University of Chicago.

Heckman, J., and R. Robb. (1986). "Alternative Methods for Solving the Problem of Selection Bias in Evaluating the Impact of Treatment on Outcomes" in Drawing Inferences from Self-Selected Samples, H. Wainer, ed., New York: Springer-Verlag. (Reprinted by Lawrence Erlbaum Associates, Mahwah, New Jersey, 2001.)

Heckman, J. and G. Sedlacek. (1985). "Heterogeneity, Aggregation, and Market Wage Functions: An Empirical Model of Self-selection in the Labor Market." Journal of Political Economy 93(6). (December 1985): $1077-1125$.

. (1990). "Self-selection and the Distribution of Hourly Wages." Journal of Labor Economics 8(1) (Part 2, January 1990): S329-63

Heckman, J. and E. Vytlacil (2001), "Structural Equations, Treatment Effects and Econometric Policy Evaluation," Fisher-Schultz Lecture, forthcoming in Econometrica. 
Hill, M. (1992), The Panel Study of Income Dynamics: A User's Guide, Newbury Park, CA: Sage Publications.

Imbens, G., and J. Angrist. (1994). "Identification and Estimation of Local Average Treatment Effects," Econometrica, 62(2): 467-75.

Judd, K. (2000), "Is Education as Good as Gold? A Portfolio Analysis of Human Capital Investment." Unpublished manuscript, Stanford University.

Kane, T. (1994). "College Entry by Blacks since 1970: The Role of College Costs, Family Background, and the Returns to Education," The Journal of Political Economy, 102(5): 878-911. (1996), "College Costs, Borrowing Constraints and the Timing of College Entry" Eastern Economic Journal 22(2): 181-194.

(1999), The Price of Admission: Rethinking How Americans Pay for College Washington, DC: Brookings Institution.

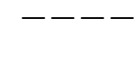

Foundation.

Keane, M. and Wolpin, K. (2001). "The Effect of Parental Transfers and Borrowing Constraints on Educational Attainment," International Economic Review, 42(4): 1051-1103.

Krueger, A. (2002), "Inequality: Too Much of a Good Thing,", In J. Heckman and A. Krueger, Inequality in America: What Role for Human Capital Policies. Cambridge: MIT Press, forthcoming 2003.

Meghir, C. and M. Palme (1999). "Assessing the Effect of Schooling on Earnings Using a Social Experiment." Institute for Fiscal Studies Working Paper W99/10.

Mulligan, C. (1997), "Notes on Tuition Sensitivity in the Becker-Tomes Model", unpubllished manuscript, University of Chicago

Orfield, G. (1992). "Money, Equity, and College Access," Harvard Educational Review, 2(3): 337-372.

Sattinger, M. (1978). "Comparative Advantage in Individuals", Review of Economics and Statistics, $60(2): 259-267$. . (1980). Capital and the Distribution of Labor Earnings. New York: North-Holland. Shea, J. (2000). "Does Parent's Money Matter?” Journal of Public Economics, 77(2): 155-84. 
Stanley, M. (1999). "Education, Opportunity, and the Mid-Century G.I. Bills." Working paper, Harvard University.

Taber, C. (2001). "The Rising College Premium in the Eighties: Return to College or Return to Unobserved Ability?" Review of Economic Studies, 68(3): 665-91.

Vytlacil, E. (2002). "Independence, Monotonicity, and Latent Index Models: An Equivalence Result," Econometrica, 70(1): 331-41.

Willis, R. and S. Rosen (1979). "Education and Self-Selection," Journal of Political Economy, 87(5): S7-36.

\section{Appendix}

Table 1 uses a sample of white males from NLSY79. Distance to four-year colleges, tuition and local labor market variables are computed using the county of residence at age 17 . When it is not possible to get the county of residence at age 17 for a given person we use the county of residence at 14 . For details of the construction of these variables see Carneiro, Heckman and Vytlacil (2001) and Carneiro, Hansen and Heckman (2001). AFQT is corrected by the following procedure: first group people by completed schooling (dropout, high school graduate, GED, some two-year college, two-year degree, some four-year college, four-year degree); then within completed schooling group regress raw AFQT scores on schooling at test date. Corrected AFQT is the intercept plus the residual of the regression. See Hansen, Heckman and Mullen (2002). This adjustment does not affect the estimates based on the unadjusted test scores.

Tables 3 and 4 and Figures 4-7 are for a sample of white males in NLSY79. We require everyone to have a valid family income observation at 17 or in 1979 and also a valid AFQT observation. In Figure 4 (and 6) we organize individuals into family income - AFQT cells and then compute the percentage of people enrolled in college (completing four-year college) within each of these cells. In Figure 5 (and 7) we first regress college enrollment (completion of four-year college) on a set of family background variables and then compute the average residual for each family income - AFQT cell. We do this same residualization in Table 3 (but for many more dimensions of college participation) and then estimate, within each AFQT 
tercile, what is the gap in (adjusted) college enrollment (completion, delay of entry, type of college) between each quartile of family income and the top quartile. This gap can be negative. The last line of each panel presents a joint F-test that all gaps are equal to zero. We equate these gaps with the proportion of people credit constrained within each family income - ability cell (assuming no one is constrained in the top income quartile). Then to get Table 4 we multiply these gaps by the percentage of the population in each cell. Panel A shows that $6.41 \%$ of the population is constrained. $1.32 \%$ of these $6.41 \%$ is in the low AFQT low-income cell.

Figure 8 is for individuals in all race and gender groups in Children of NLSY79. The same patterns hold within race-gender groups. 
Table 1

Sample correlations for Instrument (Z), schooling (S) and AFQT (A)

White Males, NLSY79

\begin{tabular}{|c|c|c|c|c|c|}
\hline Instrument & $\rho_{Z, S}$ & $\rho_{Z, A}$ & $\rho_{S, A}$ & $\rho_{S, A} * \rho_{S, Z}$ & $\begin{array}{c}\rho_{Z, A}>\rho_{S, A} \rho_{S, Z} \text { if } \rho_{S, Z}>0 \\
\text { or } \\
\rho_{Z, A}<\rho_{S, A} \rho_{S, Z} \text { if } \rho_{S, Z}<0\end{array}$ \\
\hline number of siblings & $\begin{array}{r}-0.2155 \\
(0.0181)\end{array}$ & $\begin{array}{r}-0.1286 \\
(0.0211)\end{array}$ & $\begin{array}{r}0.4233 \\
(0.0162)\end{array}$ & $\begin{array}{r}-0.0912 \\
(0.0091)\end{array}$ & Yes \\
\hline mother education & $\begin{array}{r}0.4334 \\
(0.0218)\end{array}$ & $\begin{array}{r}0.3151 \\
(0.0173)\end{array}$ & $\begin{array}{r}0.4233 \\
(0.0162)\end{array}$ & $\begin{array}{r}0.1835 \\
(0.0128)\end{array}$ & Yes \\
\hline father education & $\begin{array}{r}0.4470 \\
(0.0194)\end{array}$ & $\begin{array}{r}0.3142 \\
(0.0193)\end{array}$ & $\begin{array}{r}0.4233 \\
(0.0162)\end{array}$ & $\begin{array}{r}0.1892 \\
(0.0126)\end{array}$ & Yes \\
\hline distance to college & $\begin{array}{r}-0.0456 \\
(0.0241)\end{array}$ & $\begin{array}{r}-0.0522 \\
(0.0263)\end{array}$ & $\begin{array}{r}0.4233 \\
(0.0162)\end{array}$ & $\begin{array}{r}-0.0193 \\
(0.0100)\end{array}$ & Yes \\
\hline avg. 4-yr college tuition & $\begin{array}{r}0.0071 \\
(0.0179)\end{array}$ & $\begin{array}{r}0.0276 \\
(0.0213)\end{array}$ & $\begin{array}{r}0.4233 \\
(0.0162)\end{array}$ & $\begin{array}{r}0.0030 \\
(0.0076)\end{array}$ & Yes \\
\hline avg.local blue collar wage & $\begin{array}{r}-0.0291 \\
(0.0186)\end{array}$ & $\begin{array}{r}0.0258 \\
(0.0226)\end{array}$ & $\begin{array}{r}0.4233 \\
(0.0162)\end{array}$ & $\begin{array}{r}-0.0123 \\
(0.0080)\end{array}$ & No \\
\hline local unemployment rate & $\begin{array}{r}-0.0651 \\
(0.0198)\end{array}$ & $\begin{array}{r}-0.0403 \\
(0.0191)\end{array}$ & $\begin{array}{r}0.4233 \\
(0.0162)\end{array}$ & $\begin{array}{r}-0.0276 \\
(0.0083)\end{array}$ & Yes \\
\hline birth quarter Jan-Mar & $\begin{array}{r}0.0162 \\
(0.0175)\end{array}$ & $\begin{array}{r}0.0001 \\
(0.0204)\end{array}$ & $\begin{array}{r}0.4233 \\
(0.0162)\end{array}$ & $\begin{array}{r}0.0069 \\
(0.0073)\end{array}$ & No \\
\hline birth quarter Apr-June & $\begin{array}{r}0.0256 \\
(0.0205)\end{array}$ & $\begin{array}{r}-0.0079 \\
(0.0193)\end{array}$ & $\begin{array}{r}0.4233 \\
(0.0162)\end{array}$ & $\begin{array}{r}0.0108 \\
(0.0085)\end{array}$ & No \\
\hline birth quarter July-Sept & $\begin{array}{r}-0.0269 \\
(0.0157)\end{array}$ & $\begin{array}{r}-0.0058 \\
(0.0209)\end{array}$ & $\begin{array}{r}0.4233 \\
(0.0162)\end{array}$ & $\begin{array}{c}-0.0114 \\
(0.0067)\end{array}$ & No \\
\hline birth quarter Oct-Dec & $\begin{array}{r}-0.0145 \\
(0.0210)\end{array}$ & $\begin{array}{r}0.0140 \\
(0.0222)\end{array}$ & $\begin{array}{r}0.4233 \\
(0.0162)\end{array}$ & $\begin{array}{r}-0.0061 \\
(0.0089)\end{array}$ & No \\
\hline
\end{tabular}

- $\rho$ is the correlation coefficient

- We corrected for the effect of schooling at test date on AFQT 
Table 2

Effects for a \$1,000 Increase in Gross Tuition (Both Two- and Four-Year) on the College Entry Probabilities of High School Completers

By Family Income Quartile and By AFQT Quartile

\begin{tabular}{|c|c|c|c|}
\hline & $\begin{array}{l}\text { Whites } \\
(1)\end{array}$ & $\begin{array}{l}\text { Blacks } \\
(2)\end{array}$ & $\begin{array}{l}\text { Hispanics } \\
(3)\end{array}$ \\
\hline & \multicolumn{3}{|c|}{ A. Overall Gross Tuition Effects } \\
\hline $\begin{array}{l}\text { (1) No explanatory variables except } \\
\text { tuition in the model }\end{array}$ & -.17 & -.10 & -.10 \\
\hline $\begin{array}{l}\text { (2) Baseline specication (see note at } \\
\text { table base, includes family income and } \\
\text { background, and so forth) }\end{array}$ & -.06 & -.04 & -.06 \\
\hline $\begin{array}{l}\text { (3) Adding AFQT to the row (2) } \\
\text { specification }\end{array}$ & -.05 & -.03 & -.06 \\
\hline
\end{tabular}

(4) Top Quartile

(5) Second Quartile

(6) Third Quartile

(7) Bottom Quartile

(8) Joint Test of Equal Effects

Across Quartiles (P-values)

(9) Top Quartile

(10) Second Quartile

(11) Third Quartile

(12) Bottom Quartile

(13) Joint Test of Equal Effects

Across Quartiles (P-values)

B. By Family Income Quartiles (panel A row (2) specification)

$\begin{array}{lll}-.04 & -.01 & -.04 \\ -.06 & -.03 & -.05 \\ -.07 & -.07 & -.08 \\ -.06 & -.05 & -.08 \\ .49 & .23 & .66\end{array}$

C. By Family Income Quartiles (panel A row (3) specification)

$\begin{array}{lll}-.02 & -.02 & -.02 \\ -.06 & .00\end{array}$

$\begin{array}{lll}-.02 & .00 & -.05 \\ -.07 & .00 & -.09\end{array}$

$\begin{array}{lll}-.07 & -.05 & -.09\end{array}$

$\begin{array}{lll}-.04 & -.04 & -.07\end{array}$

$\begin{array}{lll}.34 & .45 & .49\end{array}$

D. By AFQT Quartiles (panel A row (3) specification plus tuition-AFQT interaction terms)

(14) Top Quartile

(15) Second Quartile

(16) Third Quartile

(17) Bottom Quartile

(18) Joint Test of Equal Effects

Across Quartiles (P-values)
$-.03$

$-.06$

$-.06$

$-.05$

.60
$-.02$

$-.01$

$-.03$

$-.03$

.84
$-.03$

$-.05$

$-.07$

$-.05$

.68

Gross tuition is the nominal sticker-price of college and excludes scholarship and loan support.

Notes: These simulations assume both two-year and four-year college tuition increase by $\$ 1,000$ for the population of high school completers. The baseline specification used in row(2) or panel A and rows (4) through (7) of panel B includes controls for family background, family income, average wages in the local labor market, tuition at local colleges, controls for urban and southern residence, tuition-family income interactions, estimated Pell grant award eligibility, and dummy variables, that indicate the proximity of two- and four-year colleges. Definitions of the variables are located in Table 4. The Panel D specification adds AFQT and an AFQT-tuition interaction to the baseline specification 
Table 3

NLSY79 White Males - Gaps in Enrollment, Completion, Delay, Type of College

(Measured from the Highest Income Quartile) Conditioning on

Parental Education, Number of Siblings, Broken Home, South, Urban

\section{$\begin{array}{llll}\text { AFQT Tercile } 1 & \text { AFQT Tercile } 2 & \text { AFQT Tercile } 3 & \text { Total }\end{array}$}

Beta Std. Er. t-stat Beta Std. Er. t-stat Beta Std. Er. t-stat Beta Std. Er. t-stat

\section{Panel A - Enrollment in College}

\begin{tabular}{|c|c|c|c|c|c|c|c|c|c|c|c|c|}
\hline q1-q4 & -0.1223 & 0.0648 & -1.8900 & -0.1195 & 0.0635 & -1.8800 & -0.0573 & 0.0611 & -0.9400 & -0.1579 & 0.0337 & -4.6900 \\
\hline$q 2-q 4$ & & & -1.3000 & -0.0857 & 0.0554 & -1.5500 & -0.0551 & 39 & -1.0200 & -0.1137 & 0.0317 & -3.5900 \\
\hline & .0839 & & -1.2900 & 0.0339 & & -0.6700 & -0.1100 & & -2.1900 & -0.0913 & 0.0304 & -3.0000 \\
\hline & \multicolumn{3}{|c|}{$\mathrm{F}(3,459)=1.1900$} & \multicolumn{3}{|c|}{$\mathrm{F}(3,504)=1.5300$} & \multicolumn{3}{|c|}{$\mathrm{F}(3,496)=1.6100$} & \multicolumn{3}{|c|}{$\mathrm{F}(3,1611)=8.2100$} \\
\hline \multicolumn{13}{|c|}{ Panel B - Complete 4 Yr College } \\
\hline & & & & -0.0954 & 0.1015 & -0.9400 & 0.0531 & & & & 0.0562 & -0.6100 \\
\hline$-\alpha$ & & & 00 & & & & & & & & 490 & 800 \\
\hline & & & & & & & & & & & & -0.0800 \\
\hline & \multicolumn{3}{|c|}{$\mathrm{F}(3.105)=0.9700$} & \multicolumn{3}{|c|}{$\mathrm{F}(3.257)=0.9700$} & \multicolumn{3}{|c|}{$F(3.277)=0.6900$} & \multicolumn{3}{|c|}{$F(3,697)=0.5000$} \\
\hline \multicolumn{13}{|c|}{ Panel C - Complete 2 Yr College } \\
\hline & & & & -0.1378 & & & & & & & & -0.8800 \\
\hline $2-\mathrm{q} 4$ & .1889 & 0.2160 & -0.8700 & -0.0929 & 0.13 & -0.6 & 0.0572 & 561 & 1.0200 & -0.0166 & 0.0769 & -0.2200 \\
\hline$q 3-q 4$ & .0134 & 0.2072 & -0.0600 & 0.0059 & 0.1301 & 0.0 & 0.0431 & 0.0586 & 0.7400 & 0.1357 & 0.0745 & 1.8200 \\
\hline All Gaps $=0$ & \multicolumn{3}{|c|}{$F(3,46)=1.1200$} & \multicolumn{3}{|c|}{$\mathrm{F}(3,73)=0.4300$} & \multicolumn{3}{|c|}{$F(3.81)=0.6600$} & \multicolumn{3}{|c|}{$F(3,224)=2.6200$} \\
\hline
\end{tabular}

Panel D - Proportion of People not Delaying College Entry

\begin{tabular}{|c|c|c|c|c|c|c|c|c|c|c|c|c|}
\hline 1-q4 & & 0.19 & -0.6 & 0.06 & & & & & & & & \\
\hline 2 & .3403 & 0.1718 & -1.9800 & -0.0880 & 1052 & -0.8400 & -0.1269 & 0.0877 & -1.4500 & -0.1758 & 0.0625 & 100 \\
\hline & & & -1.8400 & 0.0403 & 0.0873 & & & 0.0904 & -0.7100 & -0.0634 & & -1.0900 \\
\hline - & \multicolumn{3}{|c|}{$F(3.59)=1.7700$} & \multicolumn{3}{|c|}{$\mathrm{F}(3.128)=0.6000$} & \multicolumn{3}{|c|}{$\mathrm{F}(3.140)=0.8700$} & \multicolumn{3}{|c|}{$\mathrm{F}(3.354)=2.8200$} \\
\hline
\end{tabular}

\begin{tabular}{|c|c|c|c|c|c|c|c|c|c|c|c|}
\hline \multicolumn{12}{|c|}{ Panel E - Years of Delay of College Entry } \\
\hline$q 1-q 4$ & 0.0985 & 0.0800 & 0.6206 & 0.7404 & 0.8400 & 0.3185 & 0.4714 & 0.6800 & 0.4275 & 0.4160 & 1.0300 \\
\hline$q 2-q 4$ & 2.0706 & 1.1642 & 1.1833 & 0.5217 & 2.2700 & 0.7943 & 0.3675 & 2.1600 & 1.4265 & 0.3252 & 4.3900 \\
\hline q3-q4 & 1.1817 & $1.1894 \quad 0.9900$ & 0.2604 & 0.4331 & 0.6000 & 0.3185 & 0.3788 & 0.8400 & 0.5342 & 0.3040 & 1.7600 \\
\hline All Gaps $=0$ & \multicolumn{2}{|c|}{$\mathrm{F}(3.59)=1.4400$} & \multicolumn{3}{|c|}{$\mathrm{F}(3,128)=1.8300$} & \multicolumn{3}{|c|}{$\mathrm{F}(3.140)=1.5600$} & \multicolumn{3}{|c|}{$\mathrm{F}(3.354)=6.4700$} \\
\hline \multicolumn{12}{|c|}{ Panel F - Enrollment in 4 Yr vs 2 Yr College } \\
\hline q1-q4 & 0.1332 & 1.1800 & -0.0158 & 0.0749 & -0.2100 & -0.1011 & 0.0678 & 900 & -0.0100 & 0.0438 & -0.2300 \\
\hline$q 2-q 4$ & -0.0857 & $0.1029-0.8300$ & -0.0371 & 0.0637 & -0.5800 & -0.1104 & 0.0577 & -1.9100 & -0.0537 & 0.0382 & -1.4100 \\
\hline$q 3-q 4$ & -0.1767 & $0.1008-1.7500$ & 0.0311 & 0.0549 & 0.5700 & -0.0175 & 0.0544 & -0.3200 & -0.0220 & 0.0352 & -0.6300 \\
\hline All Gaps $=0$ & \multicolumn{2}{|c|}{$\mathrm{F}(3.155)=2.9500$} & \multicolumn{3}{|c|}{$\mathrm{F}(3.334)=0.4200$} & \multicolumn{3}{|c|}{$\mathrm{F}(3.362)=1.6800$} & \multicolumn{3}{|c|}{$F(3.925)=0.6900$} \\
\hline
\end{tabular}

*q1-q4 -- Gap in enrollment between quartiles 1 and 4

*q2-q4 -- Gap in enrollment between quartiles 2 and 4

*q3-q4 -- Gap in enrollment between quartiles 3 and 4

*All Gaps $=0$-- Joint test for equality for enrollment across income groups

Notes: All gaps are measured relative to the highest income group within each ability class.

Each of the first three columns in these tables represents a different AFQT tercile. The last column groups all test score terciles in one group.

Each of the first three rows corresponds to a different comparison between two income quartiles. The baseline quartile is the richest.

Ex: The gap in college enrollment between the lowest and the highest income quartile within the highest AFQT tercile is 0.0832 .

See Appendix A for the definition of the sample. 
Table 4

Percentage of Population Constrained [In Box] and

Breakdown by Components Into Income and Test Groups

\begin{tabular}{|c|c|c|c|c|}
\hline & $\begin{array}{c}\text { AFQT } \\
\text { Tercile 1 }\end{array}$ & $\begin{array}{c}\text { AFQT } \\
\text { Tercile } 2 \\
\end{array}$ & $\begin{array}{c}\text { AFQT } \\
\text { Tercile 3 }\end{array}$ & Total \\
\hline \multicolumn{5}{|c|}{ Panel A - Enrollment in College } \\
\hline Income Quartile 1 & 0.0132 & 0.0083 & 0.0039 & 0.0254 \\
\hline Income Quartile 2 & 0.0075 & 0.0068 & 0.0044 & 0.0187 \\
\hline Income Quartile 3 & 0.0068 & 0.0035 & 0.0097 & 0.0200 \\
\hline Total & 0.0275 & 0.0186 & 0.0180 & 0.0641 \\
\hline \multicolumn{5}{|c|}{ Panel B - Complete 4 Yr College } \\
\hline Income Quartile 1 & -0.0184 & 0.0066 & -0.0036 & -0.0154 \\
\hline Income Quartile 2 & -0.0167 & 0.0063 & 0.0021 & -0.0084 \\
\hline Income Quartile 3 & -0.0108 & -0.0039 & 0.0055 & -0.0093 \\
\hline Total & -0.0459 & 0.0090 & 0.0039 & $-0.0330(a)$ \\
\hline \multicolumn{5}{|c|}{ Panel C - Complete 2 Yr College } \\
\hline Income Quartile 1 & 0.0440 & 0.0096 & -0.0057 & 0.0479 \\
\hline Income Quartile 2 & 0.0171 & 0.0074 & -0.0046 & 0.0199 \\
\hline Income Quartile 3 & 0.0011 & -0.0006 & -0.0038 & -0.0033 \\
\hline Total & 0.0621 & 0.0164 & -0.0141 & 0.0645 \\
\hline \multicolumn{5}{|c|}{ Panel D - Proportion of People not Delaying College Entry } \\
\hline Income Quartile 1 & 0.0126 & -0.0047 & -0.0016 & 0.0064 \\
\hline Income Quartile 2 & 0.0308 & 0.0070 & 0.0101 & 0.0479 \\
\hline Income Quartile 3 & 0.0262 & -0.0041 & 0.0057 & 0.0278 \\
\hline Total & 0.0696 & -0.0018 & 0.0142 & 0.0821 \\
\hline \multicolumn{5}{|c|}{ Panel E - Enrollment in 4 Yr vs 2 Yr College } \\
\hline Income Quartile 1 & -0.0143 & 0.0011 & 0.0069 & -0.0063 \\
\hline Income Quartile 2 & 0.0077 & 0.0030 & 0.0088 & 0.0195 \\
\hline Income Quartile 3 & 0.0144 & -0.0032 & 0.0015 & 0.0127 \\
\hline Total & 0.0078 & 0.0009 & 0.0173 & 0.0260 \\
\hline
\end{tabular}

* Percentage of people constrained $=($ gap to highest income group $) *(\%$ of people in cell $)$

(a) A negative number means that the adjustment more than eliminates the gap.

\section{Notes:}

(1) We assume that agents in the highest income quartile are not constrained (whatever AFQT tercile they are in) and estimate the percentage of people constrained in each cell using the formula at the base of the table.

(2) Ex: The percentage of people constrained in their decision to enroll in college is $6.41 \%$ (see the number in the total - total cell).

(3) The low income - high AFQT group accounts for $0.4 \%$ of this number (see the number on the Income Quartile 1 - AFQT Tercile 3 cell).

(4) A negative number in this table means that the enrollment (completion, delay) gap relative to the high income group is positive. 
Figure 1

. College Participation by 18 to 24 Year Old Male

High School Completers by Parental Family Income Quartile

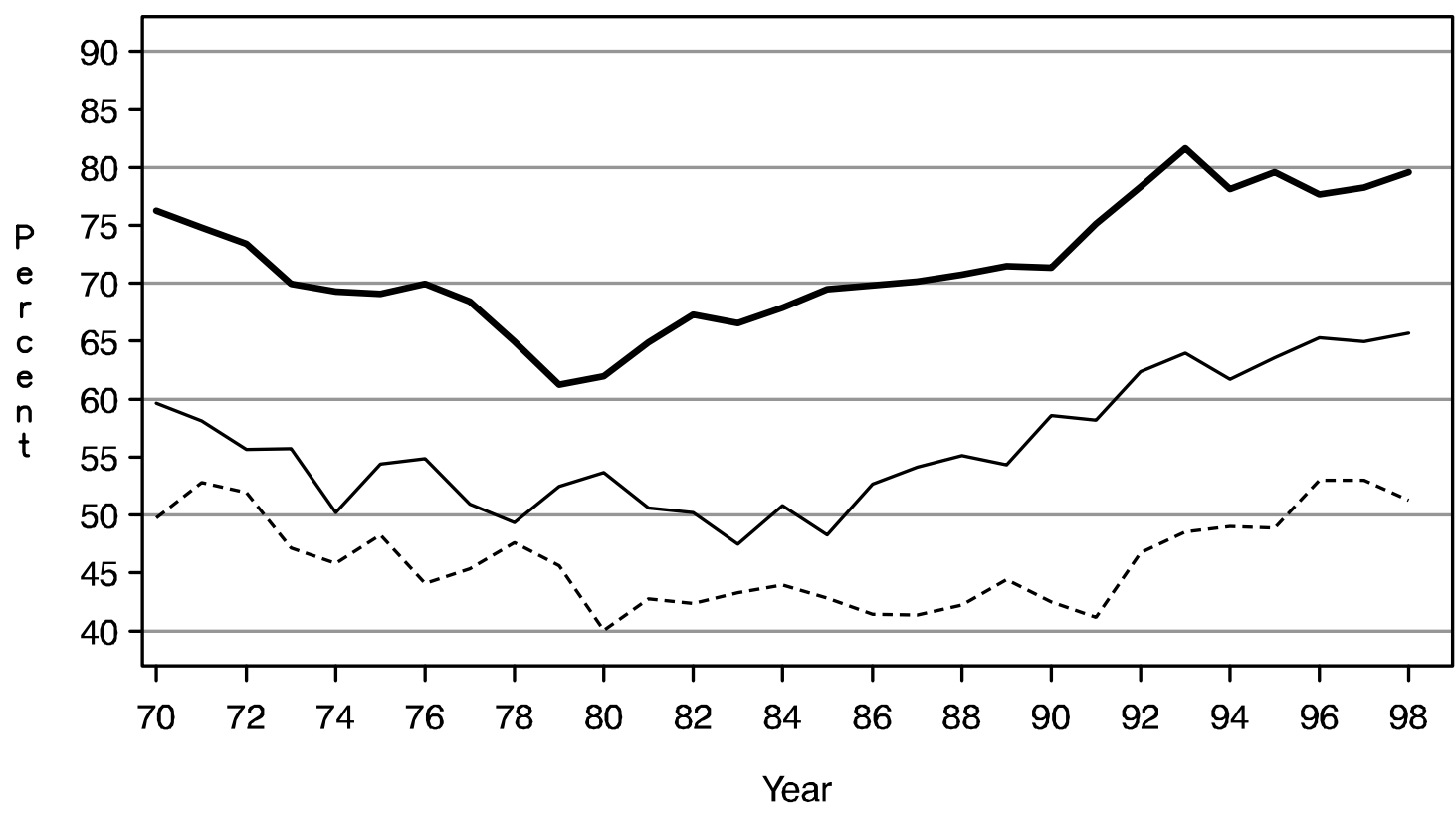

Income Quartile: $\quad$ Top Half $\quad$ Third Quartile

Source: Authors' calculations from October Current Population Survey Files

Figure 2

No Credit Constraints

Return to College

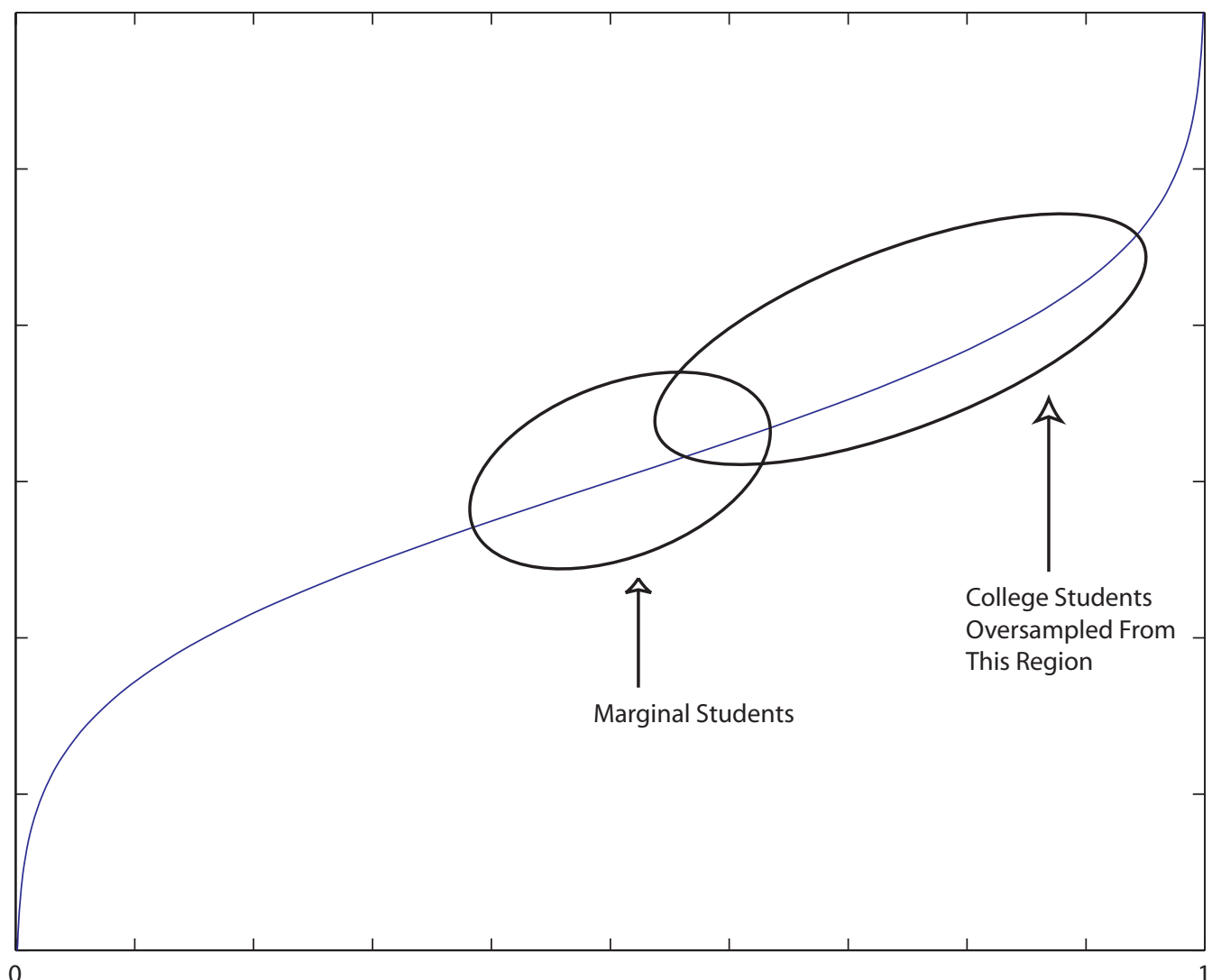


Figure 3

Credit Contrained Model

Return to College

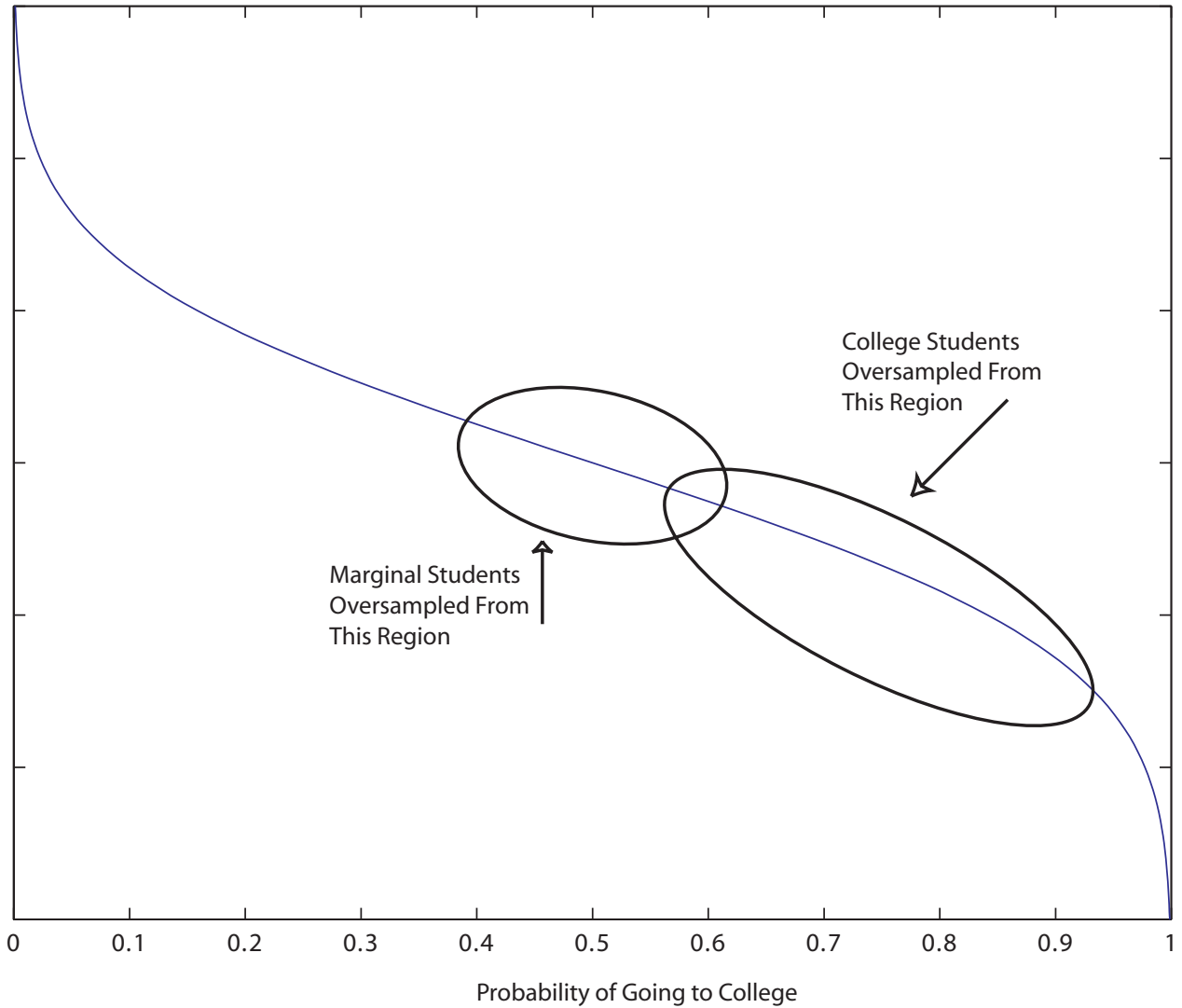

Figure 4

NLSY79 White Males - College Enrollment

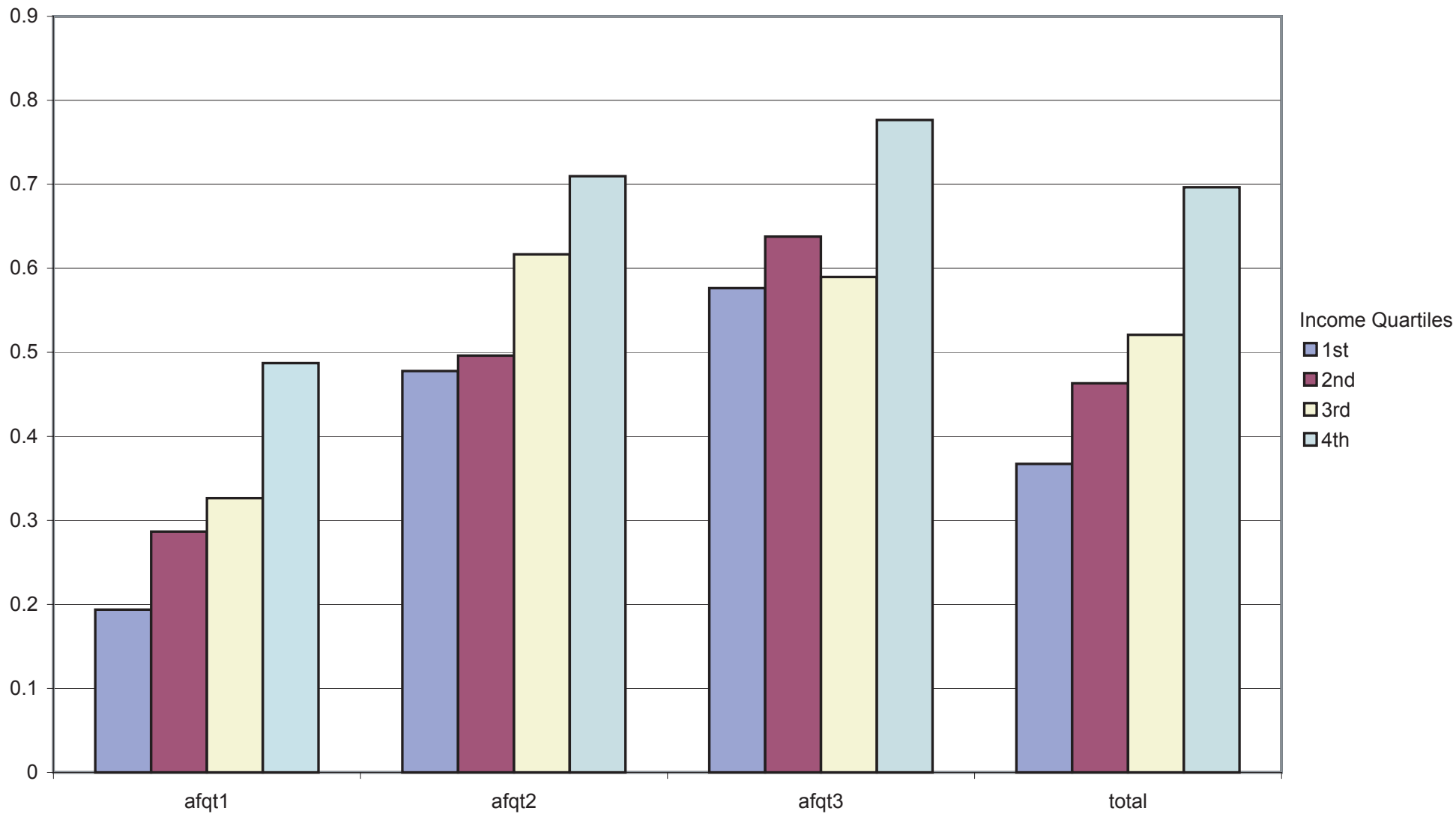

* We correct for the effect of schooling at test date on AFQT

* afqt-3 are tertiles of AFQT distribution 
Figure 5

NLSY79 White Males - Residuals of College Enrollment

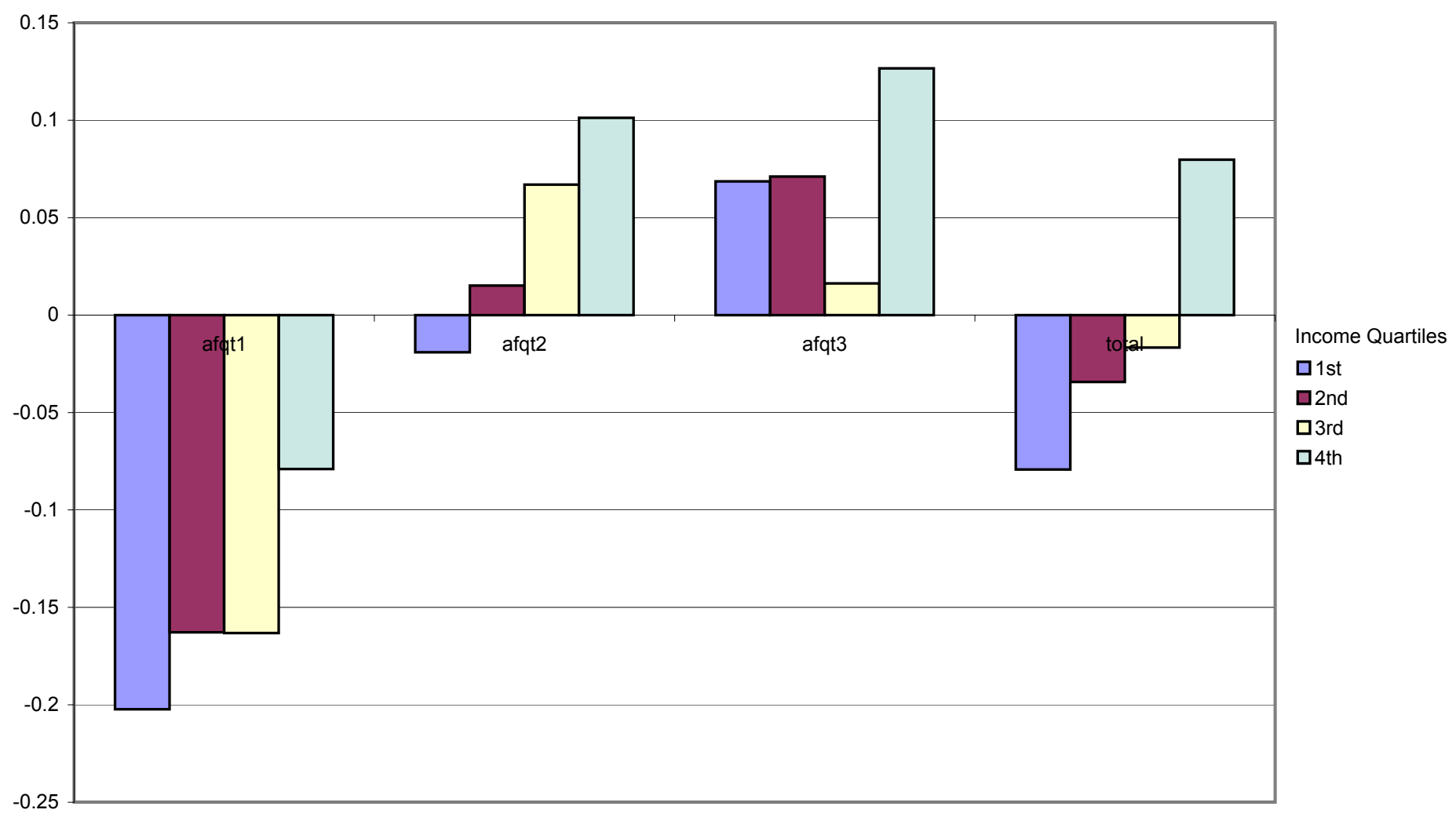

* We correct for the effect of schooling at test date on AFQT

* College Enrollment is residualized on: south, broken home, urban, number of siblings, mother's education, father's education

Figure 6

NLSY79 White Males - Completion of 4 Year College

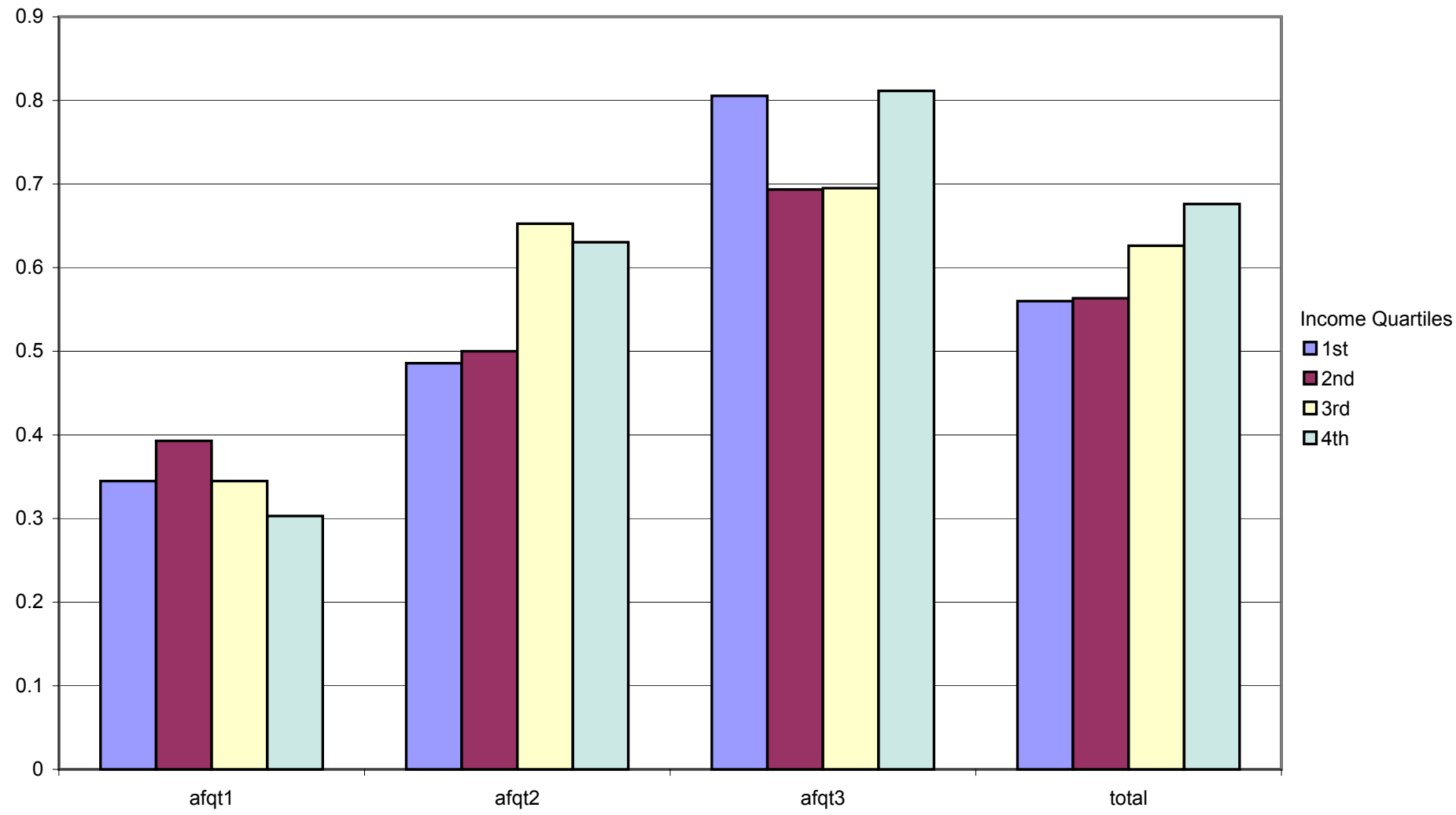

* We correct for the effect of schooling at test date on AFQT 
Figure 7

NLSY79 White Males - Residuals of Completion of 4 Year College

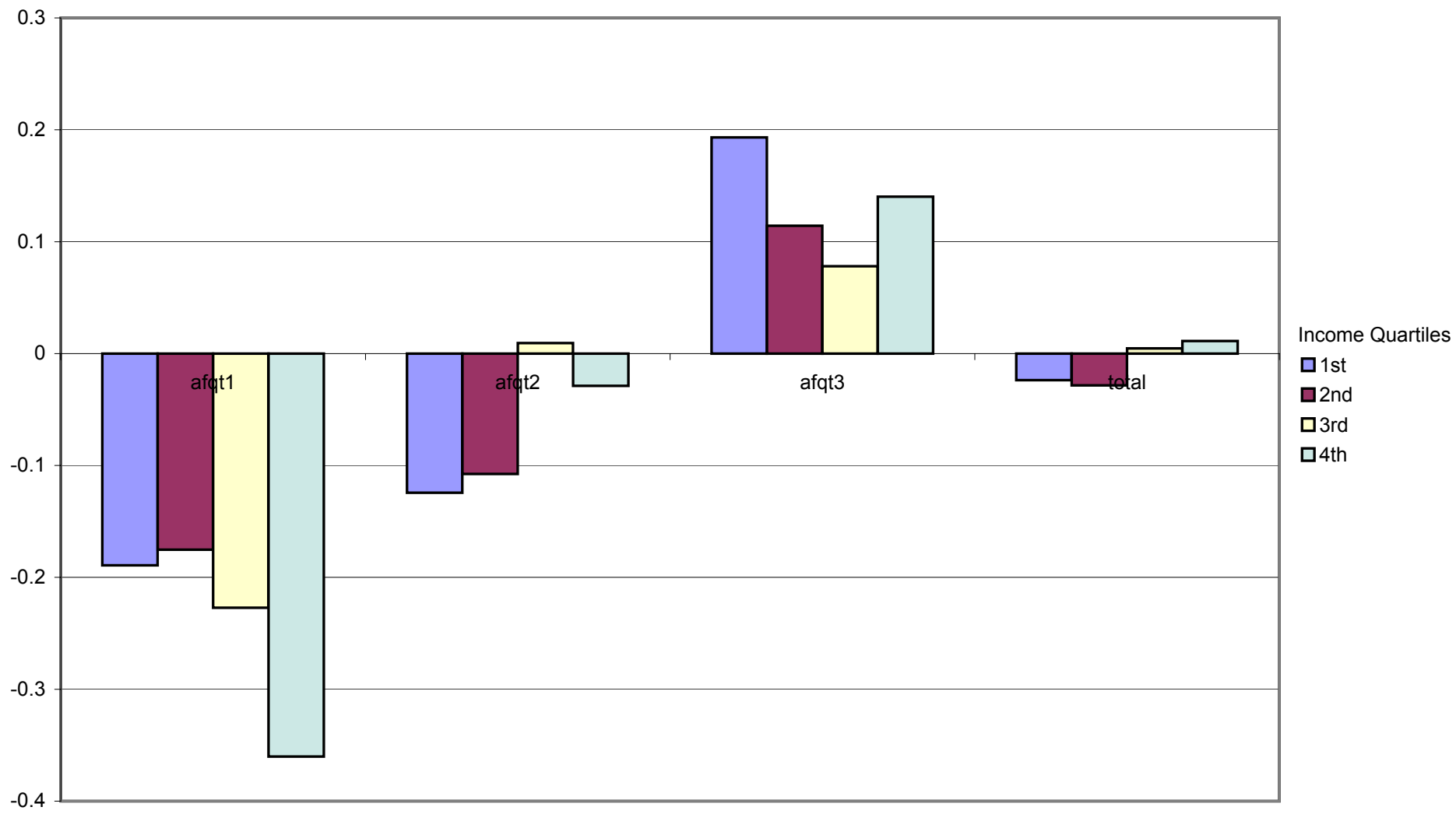

* We correct for the effect of schooling at test date on AFQT

* Completion of 4 Year College is residualized on: south, broken home, urban, number of siblings, mother's education, father's education

Figure 8

PIAT-Math Scores by Age by Family Income Quantiles - Children of NLSY79 (all race and gender groups)

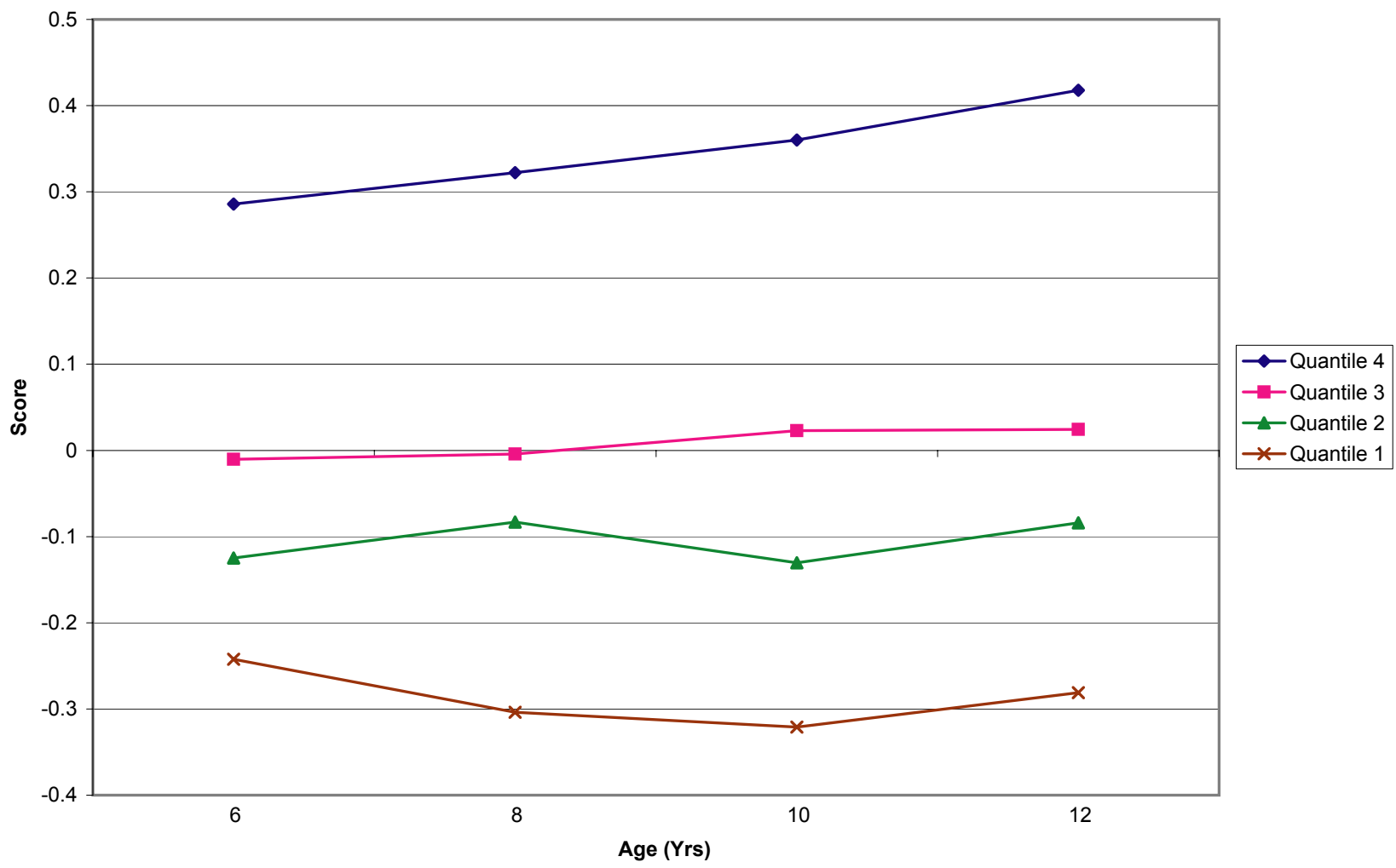

Family Income is measured at the age of the test.

For details on the PIAT-Math test see BLS (2001). 


\section{IZA Discussion Papers}

No.

501

502

503

504

505

506

507

508

509

510

511

512

513

514

515

516 H. Bonin

517

518
F. Schneider

J. Hurley

R. Vaithianathan

T. F. Crossley

D. Cobb-Clark

A. van Soest

R. Chiswick

P. W. Miller

R. Winter-Ebmer

L. Cappellari

S. P. Jenkins

P. Díaz-Vázquez

D. Snower

E. Fehr

C. Belzil

J. Hansen

A. Kunze

E. S. Prasad

$F$. Büchel

H. Battu

C. Belzil

J. Hansen

C. Belzil

J. Hansen

E. Tekin

P. Carneiro

J. J. Heckman
Title

Area

Date

Class Size, Education, and Wages

5

05/02

Immigrants' Language Skills: The Australian

1

05/02

Experience in a Longitudinal Survey

Public Funding and Enrolment into Higher

3

05/02

Education in Europe

Modelling Low Income Transitions

4

05/02

Migration, Sozialstaat und Zuwanderungspolitik

05/02

Can Insider Power Affect Employment?

05/02

Psychological Foundations of Incentives

5

05/02

Unobserved Ability and the Return to Schooling

6

05/02

The Timing of Careers and Human Capital

1

06/02

Depreciation

Wage Inequality in the United Kingdom, 1975-99

06/02

The Theory of Differential Overqualification: 1

06/02

Does it Work?

A Structural Analysis of the Correlated Random 6

Coefficient Wage Regression Model

06/02

Earnings Dispersion, Risk Aversion and

6

06/02

Education

The Size and Development of the Shadow

4

06/02

Economies of 22 Transition and 21 OECD

Countries

Parallel Private Health Insurance in Australia:

3

06/02

A Cautionary Tale and Lessons for Canada

Eine fiskalische Gesamtbilanz der Zuwanderung

7

06/02 nach Deutschland

Child Care Subsidies, Wages, and Employment

3

$06 / 02$ of Single Mothers

The Evidence on Credit Constraints in

$06 / 02$ 